\section{UKCPR}

University of Kentucky

Center for

Poverty Research

\section{Discussion Paper Series}

DP 2008-05

ISSN: 1936-9379

\title{
Homebuying in New Orleans before and after Katrina: Patterns by space, race, and income
}

\author{
Dan Immergluck \\ Georgia Institute of Technology \\ Department of City and Regional Planning \\ and \\ Yun Sang Lee \\ Georgia Institute of Technology \\ Department of City and Regional Planning
}

\section{October 2008}

\section{Preferred citation}

Immergluck, D., and Lee, Y. (2008, October). Homebuying in New Orleans before and after Katrina: Patterns by space, race, and income. University of Kentucky Center for Poverty Research Discussion Paper Series, DP2008-05. Retrieved [Date] from http://www.ukcpr.org/Publications/DP2008-05.pdf.

Address correspondence to Dan Immergluck, Georgia Institute of Technology, Department of City and Regional Planning. E-mail: dan.immergluck@coa.gatech.edu. 


\title{
Homebuying in New Orleans Before and After Katrina:
}

\section{Patterns by Space, Race and Income}

\author{
Dan Immergluck, $\mathrm{PhD}^{1}$ \\ and Yun Sang Lee ${ }^{2}$ \\ June 12, 2008 \\ Prepared for \\ The University of Kentucky Center for Poverty Research \\ Regional Small Grants Program \\ Office of the Assistant Secretary for Planning and Evaluation \\ U.S. Department of Health and Human Services
}

\begin{abstract}
Natural disasters can conceivably have significant impacts on the "neighborhood sorting” of different racial or economic groups across intrametropolitan space. Using Home Mortgage Disclosure Act data we examine mortgage-financed homebuying activity within the New Orleans MSA before and after Hurricane Katrina. We find that, while the total amount of homebuying in the 7-parish New Orleans MSA was relatively unchanged between 2004 and 2006, homebuying in the city declined significantly, and declined most in places experiencing severe storm damage. We also find that after Hurricane Katrina, the proportion of homebuyers in the region and the city who were African-American or low-income declined. Finally, we find that segregation levels of African-American and lower-income homebuyers declined in the year following Katrina. However, some of this effect is likely due to smaller overall numbers of lower-income and African-American buyers in the region.
\end{abstract}

Acknowledgement: This project was supported with a grant from the University of Kentucky Center for Poverty Research through the U.S. Department of Health and Human Services, Office of the Assistant Secretary for Planning and Evaluation, grant number 5 UO1 PE000002-05. The opinions and conclusions expressed herein are solely those of the author(s) and should not be construed as representing the opinions or policy of the UKCPR or any agency of the federal government.

\footnotetext{
${ }^{1}$ Corresponding author. Associate Professor, City and Regional Planning. Georgia Institute of Technology, Atlanta, GA 30332-0155, dan.immergluck@coa.gatech.edu.

${ }^{2} \mathrm{PhD}$ candidate, City and Regional Planning. Georgia Institute of Technology.
} 


\section{Introduction}

Among the many types of social and economic effects of Hurricane Katrina, one crucial set of impacts will be on housing and demographic patterns within the New Orleans metropolitan area and within the City of New Orleans itself. While some literature exists on the housing and demographic impacts of natural disasters, much of it has focused on emergency and temporary shelter problems, the destruction of physical stock, and patterns of reconstruction (Comerio, 1997; Lindell and Prater, 2003; Quarantelli, 1995; Quarantelli, 1999). Less work has focused on the spatial sorting impacts of disasters on the how such disasters can reshape - or not entrenched patterns of racial and economic segregation. In this paper, we look at one segment of housing demographics - buyers of owner-occupied homes - to explore differences in geographic patterns of homebuying before and after Hurricane Katrina. We do this by analyzing federal data on home purchase loans.

Within the literature addressing the effects of natural disasters on housing markets, some researchers have examined the impacts on housing values (Peacock, Zhang and Dash, 2005; Murdock, Singh and Thayer, 1993). Other literature has also addressed racial and ethnic disparities in housing impacts with some focus on rental housing, and the role of the property and casualty insurance market in the owner-occupied market, including inequalities in access to higher-quality insurance (Fothergill, Maestas and Darlington, 1999; Peacock and Girard, 1997). This study departs significantly from the bulk of the existing literature on disaster responses and recovery by focusing on the changes, following Hurricane Katrina, in the spatial patterns - by race and income - of owner-occupied homebuying activity.

The paucity of research on the spatial resorting of racial and economic groups induced by natural disasters is not surprising because policy-makers and others tend to demand information 
on the most visible effects of disasters and because disasters large enough to produce easily detectable impacts on such markets have been rare in the U.S.

It is important to note that, in this analysis, we recognize the interactions between the disaster and preexisting housing conditions and problems. Rather than simply assuming that predisaster housing markets are well functioning, highly efficient, and generally equitable, we analyze changes since the disaster on a housing system that had already exhibited substantial levels of segregation by race and income and substantial concentrations of poverty.

We find that homebuying in the New Orleans metropolitan area shifted toward increasing shares of higher-income and non-black homebuyers, both in the region as a whole, but especially in the city of New Orleans. Perhaps as might be expected, within the city of New Orleans, areas that suffered much more storm-related damage saw significant declines in overall homebuying activity, with one area in particular that so little damage seeing a very large increase in homebuying (the CBD-Warehouse district).

Within the city, much the decline in African-American and lower-income buying is attributable to a rapid decline in homebuying from 2004 to 2006 in the parts of the city where African-Americans had traditionally dominated the homebuying market, including New Orleans East, Gentilly, and the Lower Ninth/Holy Cross planning districts. We also find that, in part due to the decline in the numbers of lower-income and African-American homebuyers, the level of segregation of the homebuying patters of these groups declined both when measured by indices of dissimilarity and isolation. Finally, while most parts of the city did not see sizeable changes in non-owner-occupied homebuying, two planning districts, Lakeview and Gentilly, saw substantial increases in the share of purchases due to non-owner-occupants from 2004 to 2006. 


\section{The Context for Owner-occupied Housing in New Orleans Prior to Katrina}

...the whole process of permanent housing in the aftermath of a major disaster cannot be understood independently of the larger community context. Whatever the governmental policies and programs for rebuilding, they only develop in the context of past history and social factors operative in any given community. They are not dependent only on what happened to the housing stock in the disaster.

(Quarantelli, 1995)

The existing structure of housing markets, including segregation by race and income, are likely to be important factors in determining long-term post-disaster housing and demographic patterns. The response of housing markets to the disaster will not be independent of conditions before the hurricane. Hurricane Katrina was unparalleled in the scale of its impact on sheer numbers of residents of a major metropolitan area. Two major parishes in the New Orleans region were particularly hard hit: Orleans parish (the city of New Orleans) and St. Bernard parish. Gabe et al. (2005) estimated that 77 percent of Orleans parish population and nearly all residents of St. Bernard parish were affected by flooding and storm damage.

The housing market of the New Orleans metropolitan area and the city of New Orleans was not without its problems before Katrina struck (Hartman and Squires, 2006). The city, though historically not as segregated racially as some large cities in the Midwest and Northeast, experienced significant problems of concentrated poverty and segregation by race and income. The dissimilarity index (at the tract level) for the 7-parish MSA was 67 out of 100 in 2000, with an isolation index of 71 out of $10 .^{3}$ The city of New Orleans was, as of 2000, 67 percent African-American, while the 7-parish MSA as a whole was only 37 percent African-American.

Concentrated poverty, at least as of 2000, was a particular concern in Orleans Parish. The city’s poverty rate was approximately 28 percent in 2000, compared to a national rate of 12

\footnotetext{
${ }^{3}$ These are moderately high figures, but do not place the region among the most segregated metropolitan areas, at least in terms of black-white segregation. Detroit, Milwaukee, Chicago, and New York, for example, all had black-white dissimilarity indices of over 75 as of the 2000 census.
} 
percent, with the rate for African Americans (35 percent) being more than three times that for whites (11 percent). Moreover, among U.S. central cities, New Orleans had the second largest share of poor citizens living in high poverty census tracts (those with poverty rates of 40 percent or more) and saw the number of such tracts increase from 30 in 1980 to 49 in 2000 (Hartman and Squires, 2006).

Logan (2006) was among the first to document that damage due to Hurricane Katrina disproportionately affected minority and lower-income neighborhoods, particularly within the City of New Orleans. Storm-damaged areas were 46 percent African-American, while undamaged areas were only 26 percent African-American. Forty-six percent of homes in stormdamaged areas were renter-occupied, compared to only 31 percent in undamaged areas, and in damaged areas, the poverty rate was a cumulative 21 percent compared to 15 percent in undamaged areas. In suburban parishes, areas with higher numbers of rental units were harder hit by the storm, while in the city the high proportion of renter-occupied units meant that the impact on rental units was large, as was the impact on owner-occupied units.

Gabe et al. (2005) found that African-Americans were disproportionately impacted by Katrina, due to the extent of flooding in the city. They estimated that African-Americans accounted form 44 percent of storm victims, and accounted for 73 percent of the victims in the city. Of course, non-black residents were affected too, with Gabe et al. (2005) estimating that 63 percent of the city's non-black population being affected by the storm. They also estimate that the poor and near-poor were disproportionately affected by the storm, with more than 40 percent of the affected population having incomes below two times the poverty line. 


\section{Data and Methods}

We analyzed data on mortgage lending patterns for the New Orleans MSA for the years 2004 (pre-Katrina) and 2006 (post-Katrina). These data - the Home Mortgage Disclosure Act (HMDA) data - are collected by federal mortgage lending regulators and, for state regulated lenders, by the U.S. Department of Housing and Urban Development. HMDA data provide a rich set of microdata on loan applications, which include information on ethnicity and race of applicant, income of applicant, census tract of property, lender identity, loan size, owneroccupancy, and some pricing data on originated loans. The data now allow us to distinguish what are essentially subprime-priced loans from prime loans on an individual loan basis. ${ }^{4}$ We will also utilize multivariate models and geographic information systems to identify and quantify changes in mortgage market structure over time.

Our work in this paper is largely descriptive. We utilize GIS analysis to discern changes in the numbers and distributions of home loans within the New Orleans metropolitan area and, especially, within the City of New Orleans from 2004 to 2006. Of course, calendar 2006 is a period that follows quite closely on the heels of Katrina, and we cannot say that these patterns persisted in 2007 or are persisting in 2008. It is almost certainly the case that, given the collapse of the subprime mortgage market in 2007, things are quite different in the region now in regard to mortgage markets. What is harder to say is whether things have changed in ways that are different from changes in national markets or in other cities.

\footnotetext{
${ }^{4}$ The HMDA data actually break out loans by pricing as follows. For any first-lien loan in which the Annual Percentage Rate (APR) for the loan is more than 3 percentage points higher than the rate on a comparablematurity Treasury bond-or for any second-lien loan where the APR is more than 5 percentage points higher than the rate on a comparable-maturity Treasury bond-then the APR for the loan is reported. These loans are sometimes referred to as "rate-reported" loans or high-APR loans. In general, it is estimated that most of these loans are subprime loans, with some also being Alt-A loans, which are higher-risk loans (but not generally considered as risky as subprime loans). For our purposes, we will refer to them as "subprime loans," as has been done in much of the recent literature.
} 
In addition to changes in national mortgage markets in 2007, there were also changes in lending markets at the state and regional level, especially in regards to borrowers who were technically delinquent on their loans, that may have affected 2006 differently than 2007 or 2008. This includes the application of foreclosure moratoria by secondary market agencies, Fannie Mae and Freddie Mac, and the Federal Housing Administration (FHA).

Figures 1 and 2 provide give some context for the analysis of home purchase lending in the seven-parish MSA. They indicate the proportion of a census tract's population that was African-American in 2000 for the MSA and for the central city of New Orleans. In the later map, the boundaries of the city's 13 planning districts are also indicated. Many census tracts in the central city were predominantly African-American. Figure 1 shows that predominantly AfricanAmerican neighborhoods - those where at least 75 percent of the population was AfricanAmerican in 2000, were concentrated in the city of New Orleans as well as in St. John the Baptist parish and parts of Jefferson parish. Some mixed-race tracts-those with 25 to 75 percent African-American residents in 2000, were scattered across St. Charles, St. John the Baptist, Jefferson, Plaquemines, and to a lesser extent, St. Bernard and St. Tammany parishes.

In the city itself, Figure 2 shows that many tracts east of the central business district were predominantly African American in 2000. Tracts on the on the far northwest corner of the city, in the Lakeview area, were predominantly nonhispanic white in 2000, as were most tracts in the Uptown/Carollton area, English Turn and Venetian Isles planning districts. Mixed-race tracts were scattered throughout he central core of the city, including the Gentilly, Midcity, Algiers and Garden District planning areas. 
Figure 1. New Orleans MSA, Percentage of Residents Who Were Black, 2000

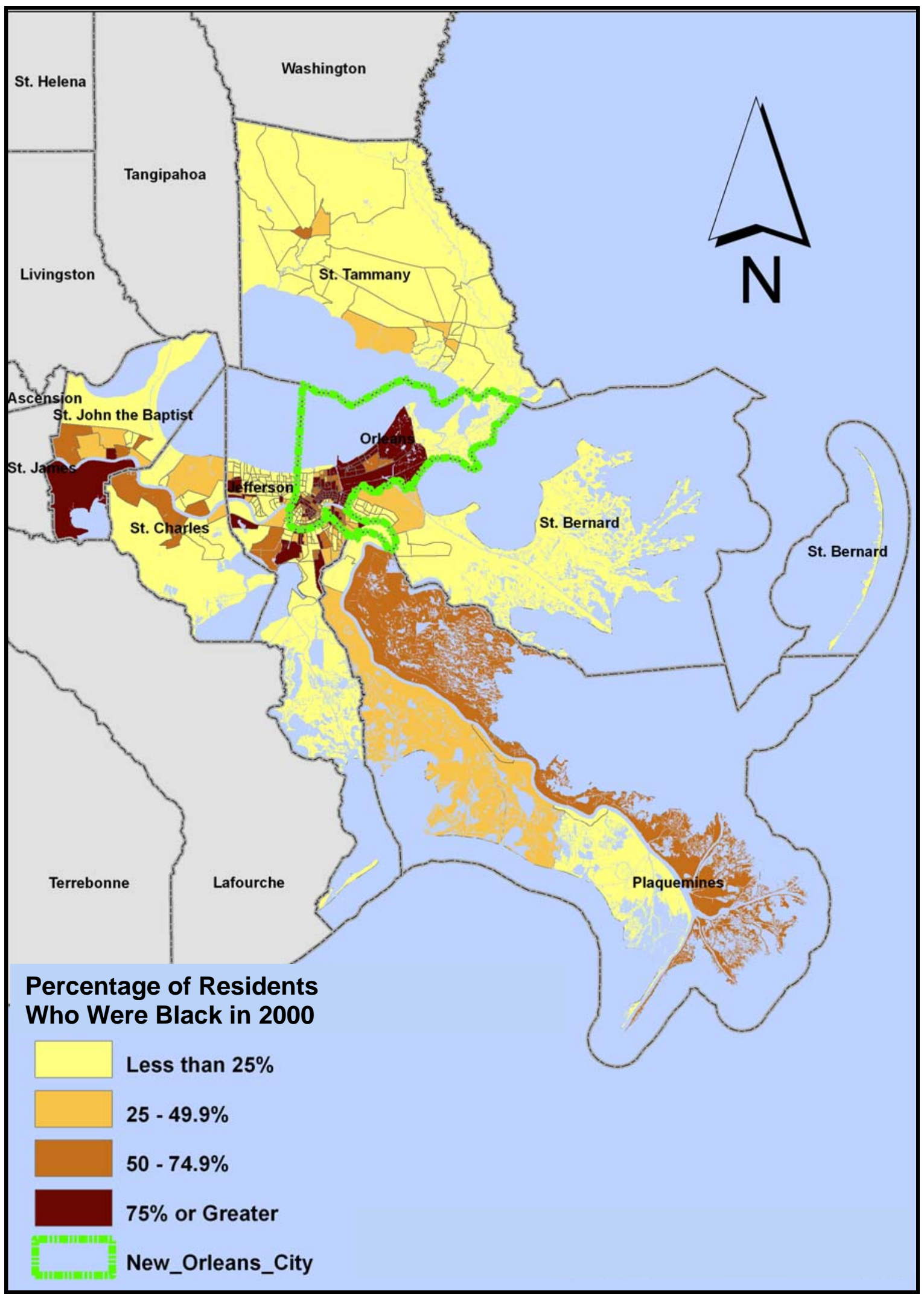


Figure 2. City of New Orleans, Percentage of Residents Who Were Black, 2000

\section{Planning Districts}

1a: CBD, Warehouse District

1b: Vieux Carre

2: Central City/Garden District

3: Uptown and Carroliton

4: Mid-City

5: Lakeview

6: Gentilly

7: Marigny, Bywater, St. Claude, St. Roch, Desire

8: Lower Ninth Ward/Holy Cross

9: New Orleans East

10: Village de L Est Area

11: Venetian Isles

12: Algiers

13: English Turn

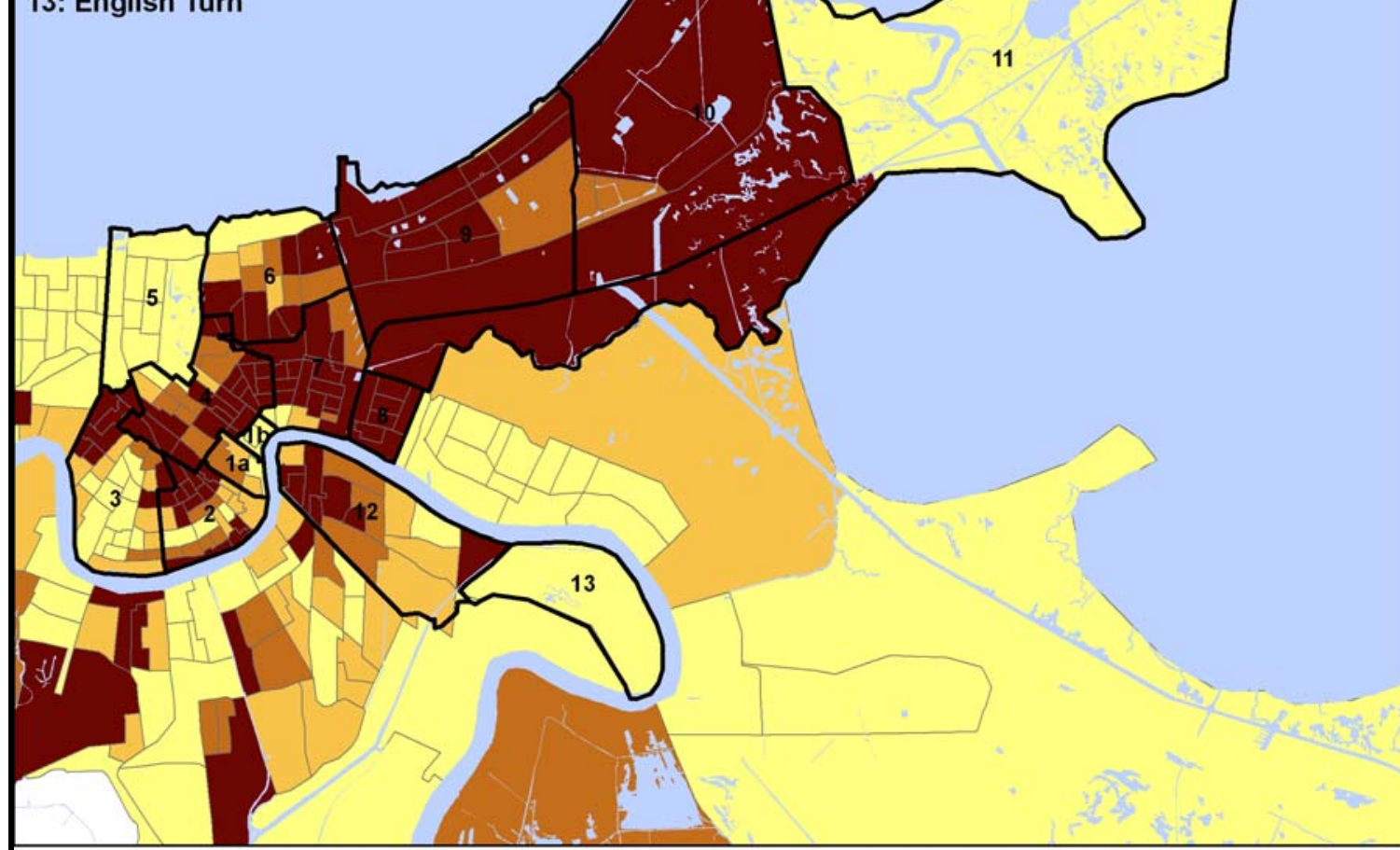

Percentage Black in 2000

Less than $25 \%$

$25-49.9 \%$

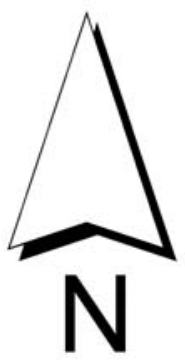

$50-74.9 \%$

$75 \%$ or Greater 


\section{Changes in the Scale and Distribution of Home Purchase Loans in the New Orleans Metropolitan Area, 2004 to 2006}

In 2006, the number of first-lien home purchase loans in the seven-parish New Orleans MSA was_-perhaps surprisingly_almost exactly the same as it was in 2004. The total number of first lien home purchase loans actually increased—although only very slightly—from 20,498 in 2004 to 20,694 in 2006. Figure 3 shows the changes in the number of first-lien purchase loans for each of the seven parishes in the MSA, and Figure 4 shows the change in the distribution of homebuyers across the parishes between the two years. Of the seven parishes in the MSA, only two, Orleans and St. Bernard, experienced a decline in first-lien purchase loans. The greatest proportional decline was in St. Bernard, which experienced a 78 percent decline from 787 to 177 loans. In the city of New Orleans (Orleans parish), purchase loans declined by 22 percent (5,823 to 4,515 ) from 2004 to 2006.

In the five other parishes, the number of first-lien home purchase loans increased, with increases ranging from 9 percent to 19 percent. The greatest rate of increase was in St. Charles parish, where first-lien purchase loans increased by 27 percent (722 to 920), followed by Jefferson parish at 19 percent $(6,399$ to 7,618), St. John the Baptist at 17 percent (190 to 932), Plaquemines at 15 percent (299 to 344), and St. Tammany at 9 percent $(5,678$ to 6,188).

In part because Jefferson and St. Tammany are the largest suburban parishes in terms of home purchase activity, they accounted for the largest segments of increased homebuying in suburban parishes, with a net increase in the two parishes together of more than 1,700 purchase loans. The remaining three parishes with increases in home purchase loans (St. John the Baptist, St. Charles, and Plaquemines) accounted for a cumulative net increase of 385 home purchase loans, less than a quarter of the net increase in the larger two parishes. 
Figure 3. Number of First-lien Home Purchase Loans by Parish, 2004 and 2006

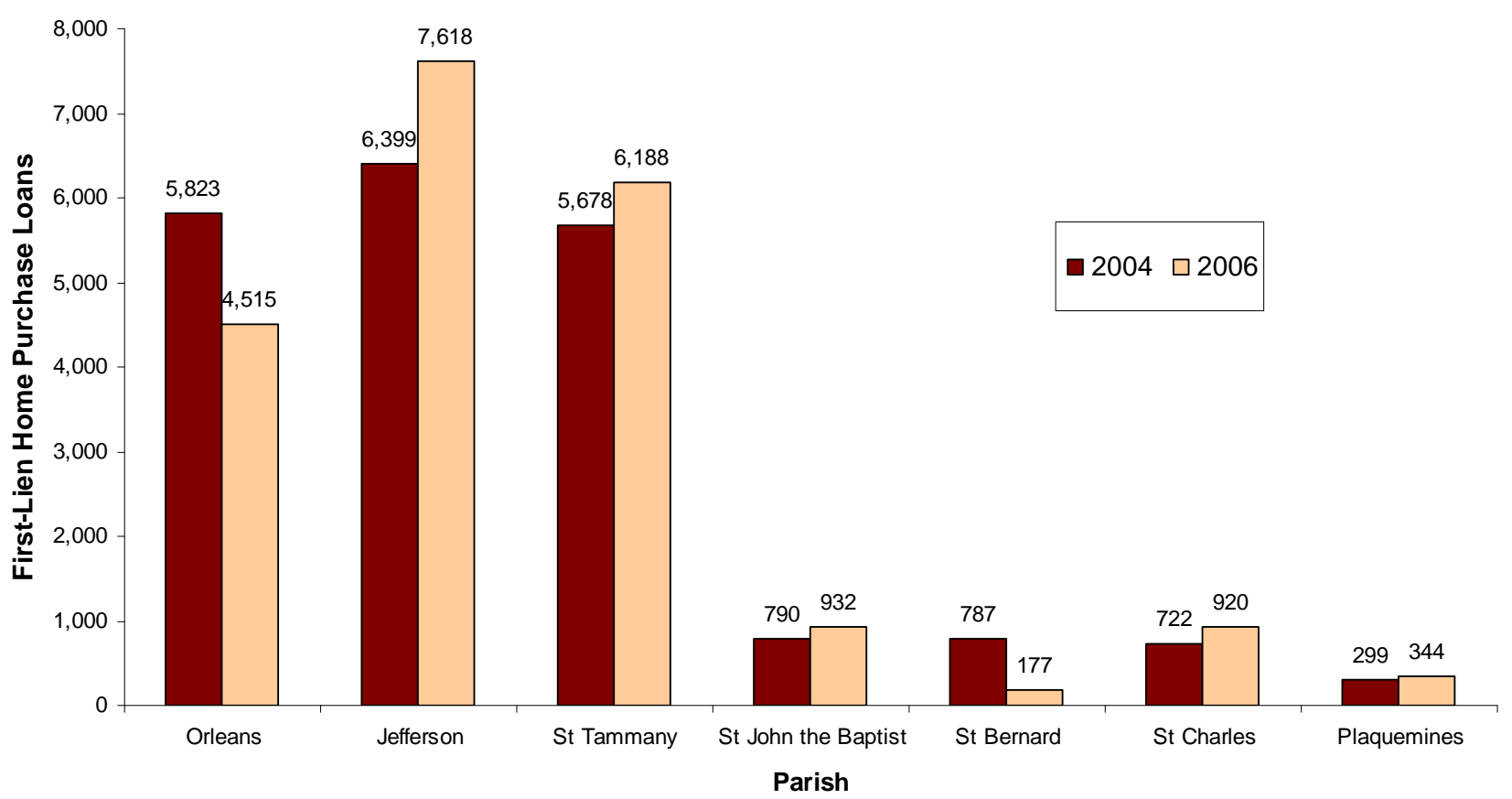

Figure 4. Parish Shares of First-lien Home Purchase Loans, 2004 and 2006
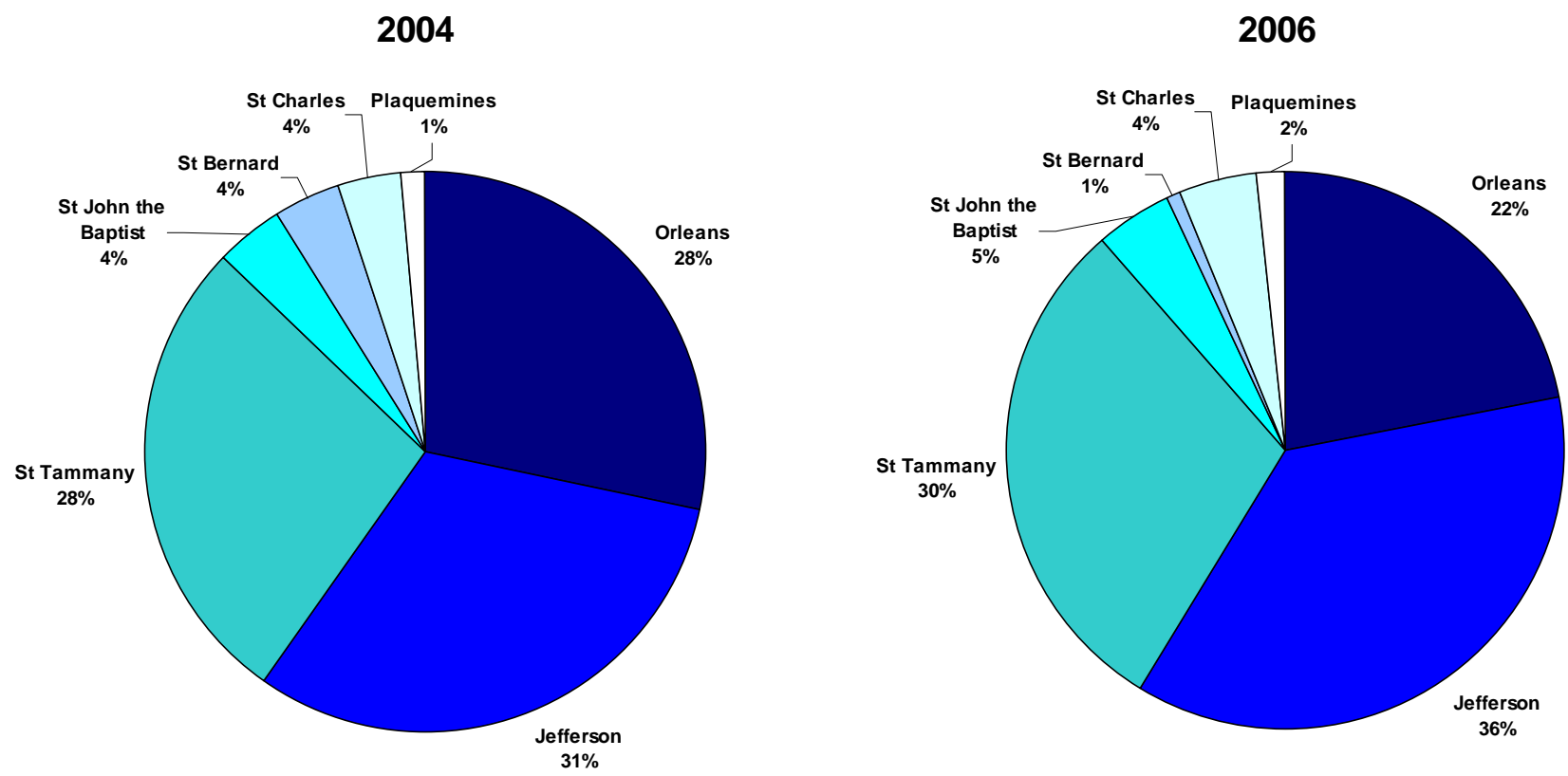
Figure 5. First-Lien Home Purchase Loans, New Orleans MSA, 2004 and 2006
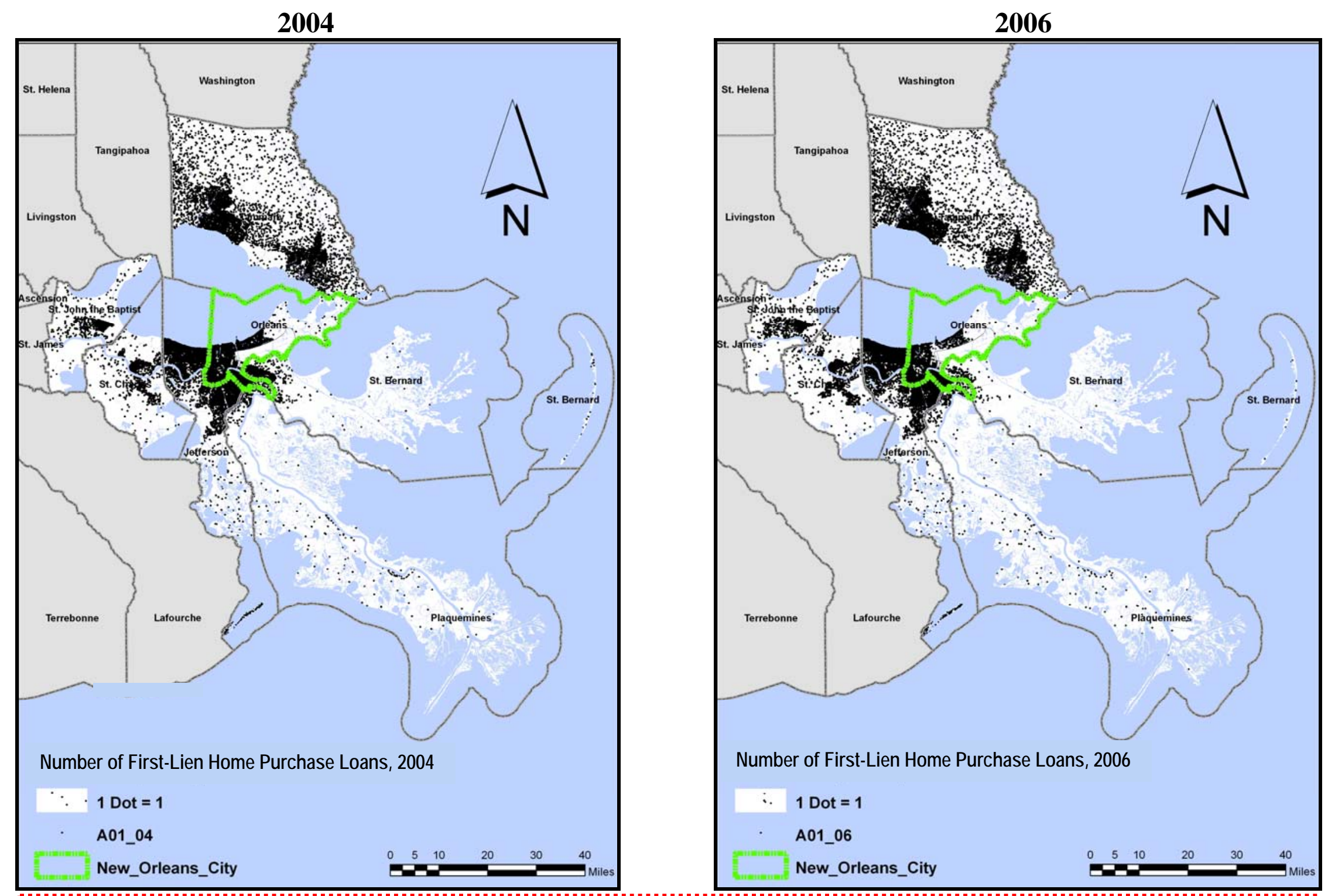

Note: These are dot-density maps at the tract level - not address-level maps. In some large tracts, dots are sometimes plotted in parts of tracts where no homes are expected to exist. 
Figure 4 describes the share of first-lien home purchase loans in the MSAs that were originated in each of the parishes in 2004 and 2006. It shows that the city of New Orleans' share of homebuying in the MSA declined from 28 percent to 22 percent, and St. Bernard’s share declined from 4 percent to 1 percent. Jefferson parish’s share increased from 31 percent to 36 percent, and St. Tammany’s increased from 28 percent to 30 percent.

Figure 5 shows the distribution of first-lien home purchase loans across census tracts in the New Orleans MSA for 2004 and 2006, respectively. (Figure 8 below does the same thing for the city of New Orleans only.) It reinforces what we know from Figure 3: that, at the MSA level, the amount of home purchase activity did not change very much over this period. Moreover, while there were important declines - and increases - in purchase loan activity in different parishes, the changes in activity were, at the parish level at least, perhaps smaller than what many might have expected.

Figure 6 indicates changes in the number purchase loans from 2004 to 2006 in the 14 different planning districts within the city of New Orleans. Here, changes in purchase loan activity become more apparent. The most noticeable declines in purchase loans from 2004 to 2006 were in the planning districts on the east side of the city, including New Orleans East, Gentilly, Martigny/Bywater, the Lower Ninth Ward-Holy Cross, and Village de Lest Area. Purchase loans also declined substantially in the Mid-City and Vieux Carre districts. Meanwhile, they either fell slightly (less than 10 percent) or increased in Algiers, CBD/Warehouse District, Central-City/Garden District, English Turn, Lakeview, and Uptown/Carrollton.

Figure 7 shows that, within the City of New Orleans, there was a clear shift in home purchase loan activity away from the east side districts toward Uptown/Carrollton, the CentralCity/Garden District and Algiers. Figure 8 illustrates the trends shown in Figures 6 and 7 via dot 
Figure 6. Number of First-lien Home Purchase Loans by City of New Orleans Planning District, 2004 and 2006

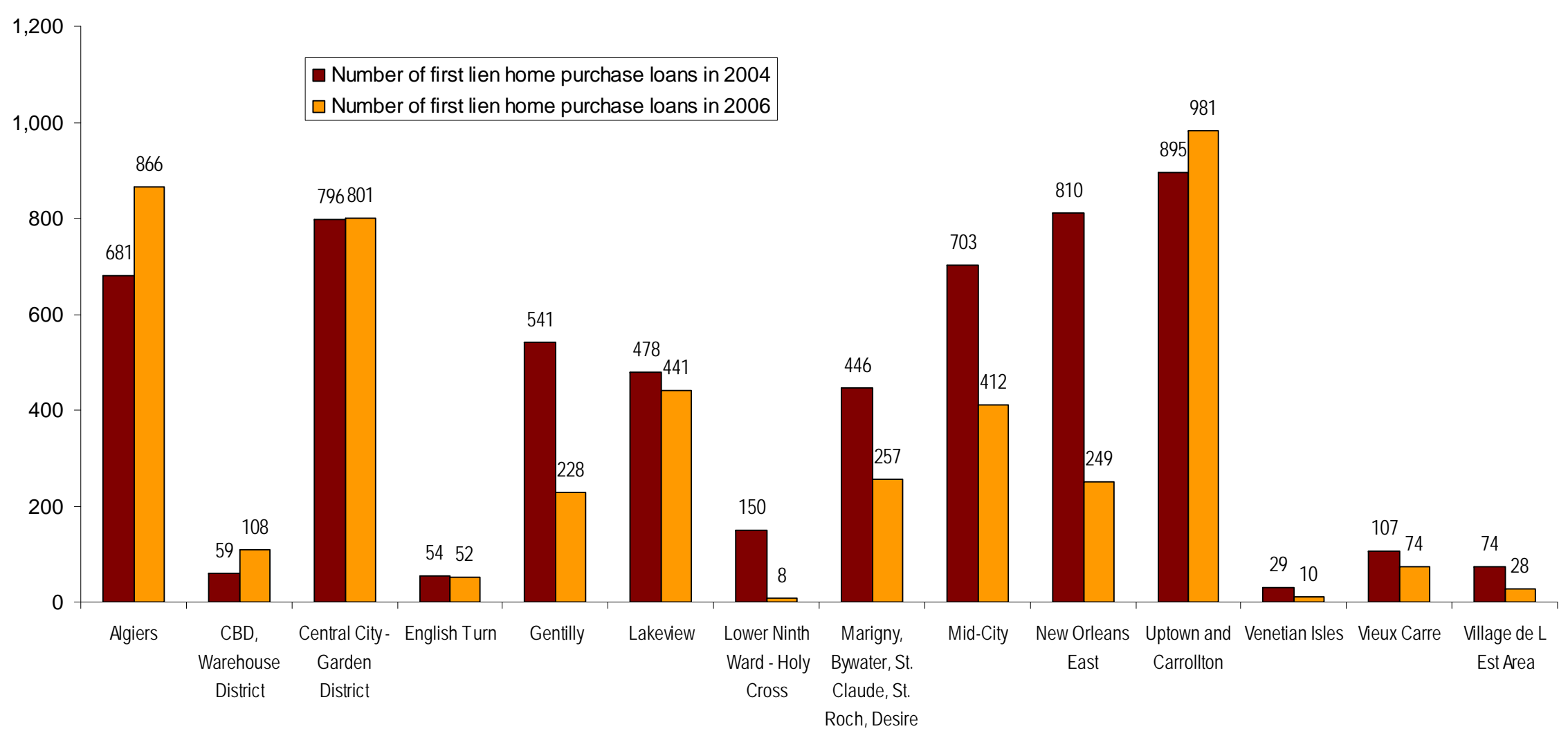


Figure 7. Parish Shares of First-lien Home Purchase Loans, 2004 and 2006

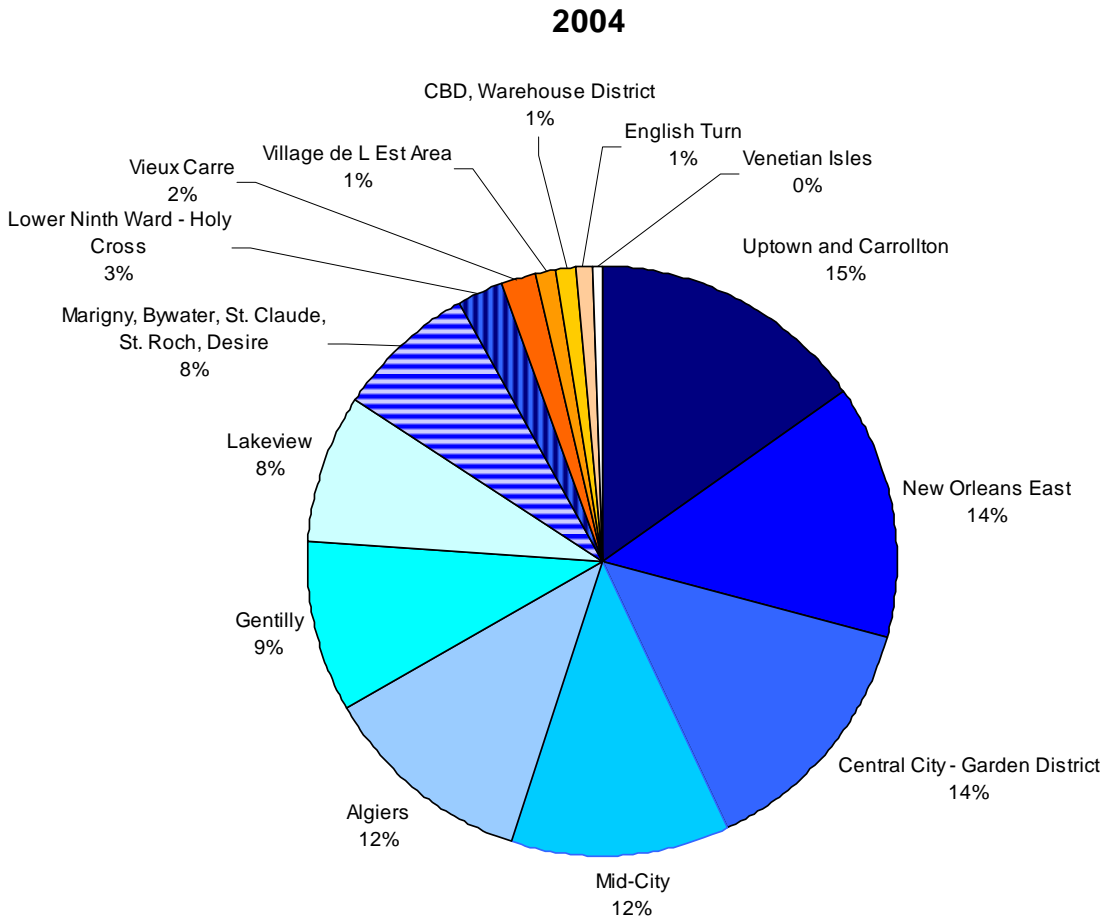

2006

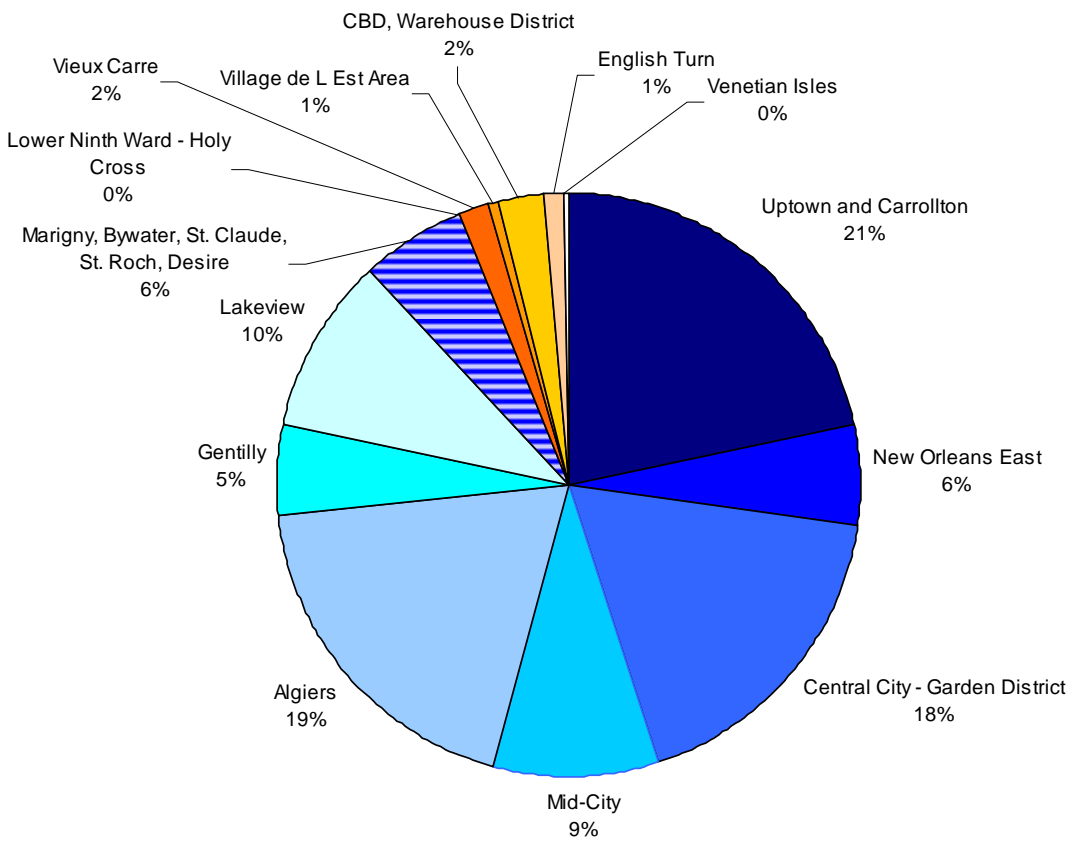


Figure 8. First-Lien Home Purchase Loans, City of New Orleans, 2004 and 2006
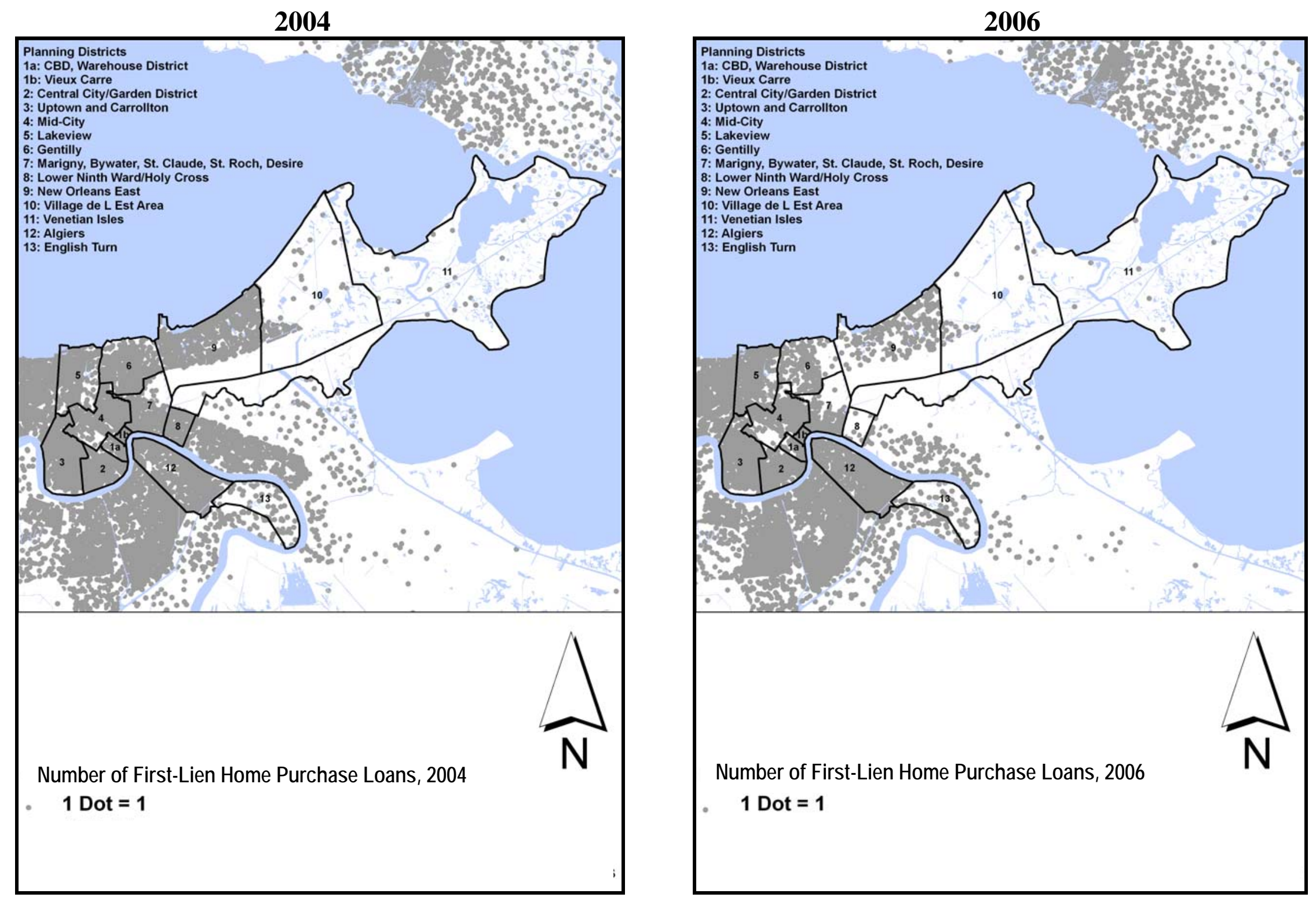

Note: These are dot-density maps at the tract level - not address-level maps. In some large tracts, dots are sometimes plotted in parts of tracts where no homes are expected to exist. 
density maps of purchase loans in the city in each of the two years. These maps also more closely illustrate the decline in lending in St. Bernard parish.

\section{Changes in Home Purchase Loans by Occupancy Status in the New Orleans Metropolitan Area, 2004 to 2006}

In the HMDA data home purchase loans are classified according to whether the mortgaged property was owner-occupied. Loans for non-owner-occupied properties are for properties bought either for vacation homes or for rental/investment purposes (or a combination of both). Figure 9 breaks out the percentage and raw numbers of non-owner-occupied first-lien home purchase loans for the seven parishes for 2004 and 2006. It shows that the percentages of loans made for nonowner-occupied properties remained quite steady over the 2004 to 2006 period. In the entire MSA, the proportion of first-lien purchase loans that went to owner-occupied properties went from 83.5 percent in 2004 to 85.1 percent in $2006 .{ }^{5}$ Figure 10 illustrates the percentages of owner-occupied loans by census tract for the entire MSA.

The proportion of loans going to owner-occupied properties was generally the lowest in Orleans parish, at 70 percent in 2004, and was above 83 percent in all other parishes. The proportion declined by more than one percentage point in only two parishes (St. Tammany, from 91.6\% to $89.5 \%$, and St. Bernard, 84.8 percent to 83.1 percent), and did not decline by more than 2.2 percentage points in any parish. Because the percentages of loans for owner-occupied properties did not change substantially at the parish level from 2004 to 2006, the distribution of first-lien, owner-occupied loans is quite similar to that of all home purchase loans, which was shown in Figures 3, 4, and 5.

\footnotetext{
${ }^{5}$ Because owner-occupied loans are considered less risky and typically carry somewhat lower interest rates, there is some incentive to claim a loan is for owner-occupancy when it is not. Thus, the HMDA data could overstate the level of owner-occupancy.
} 
Figure 9. Percent of All First-Lien Home Purchase Loans Going to Owner-Occupants and Number of First-Lien Owner-Occupied Home Purchase Loans, by Parish, 2004, 2006

\section{Percent of All First-Lien Home Purchase Loans Going to Owner-Occupants}

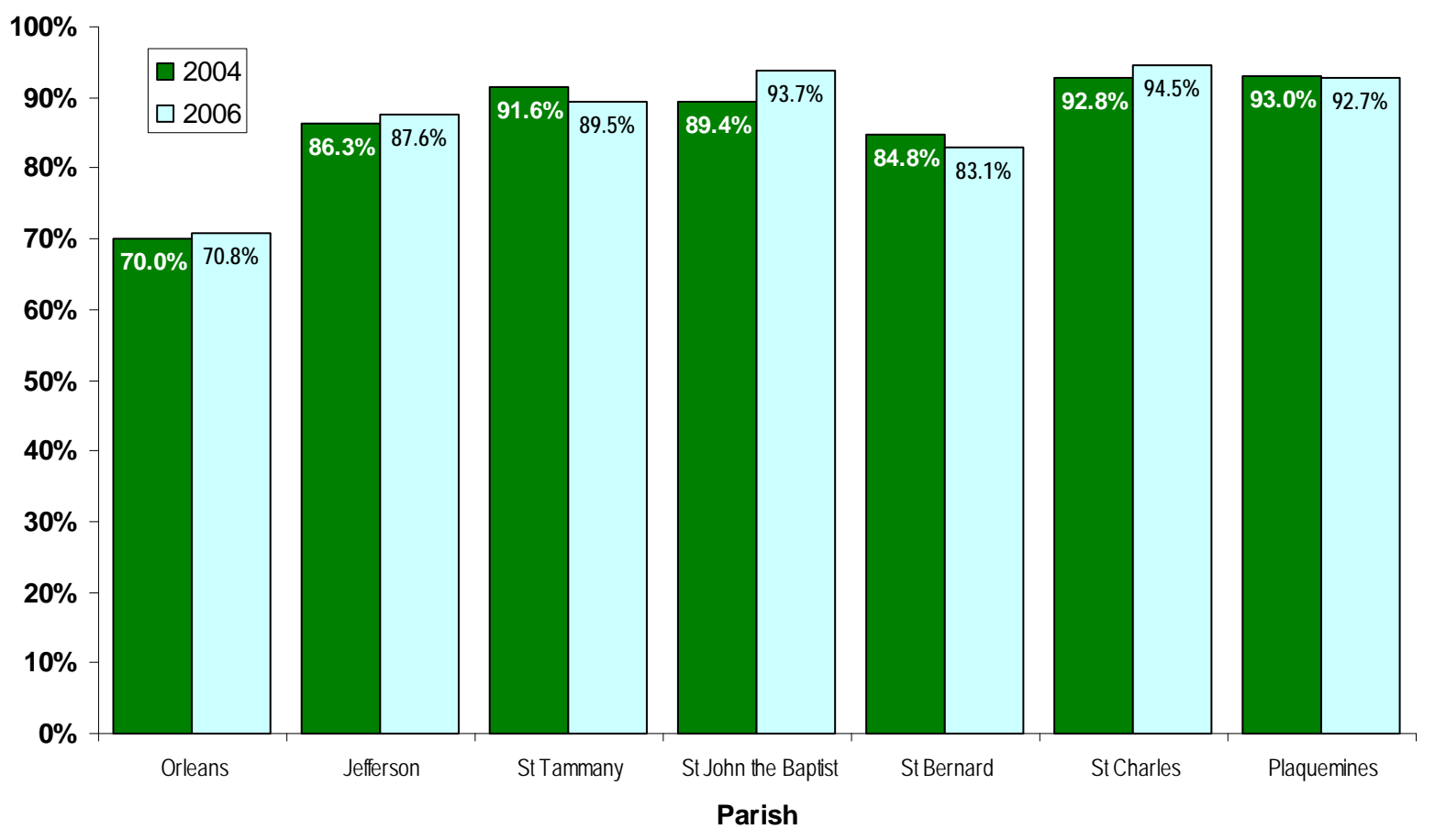

Number of First-Lien, Owner-Occupied Home Purchase Loans

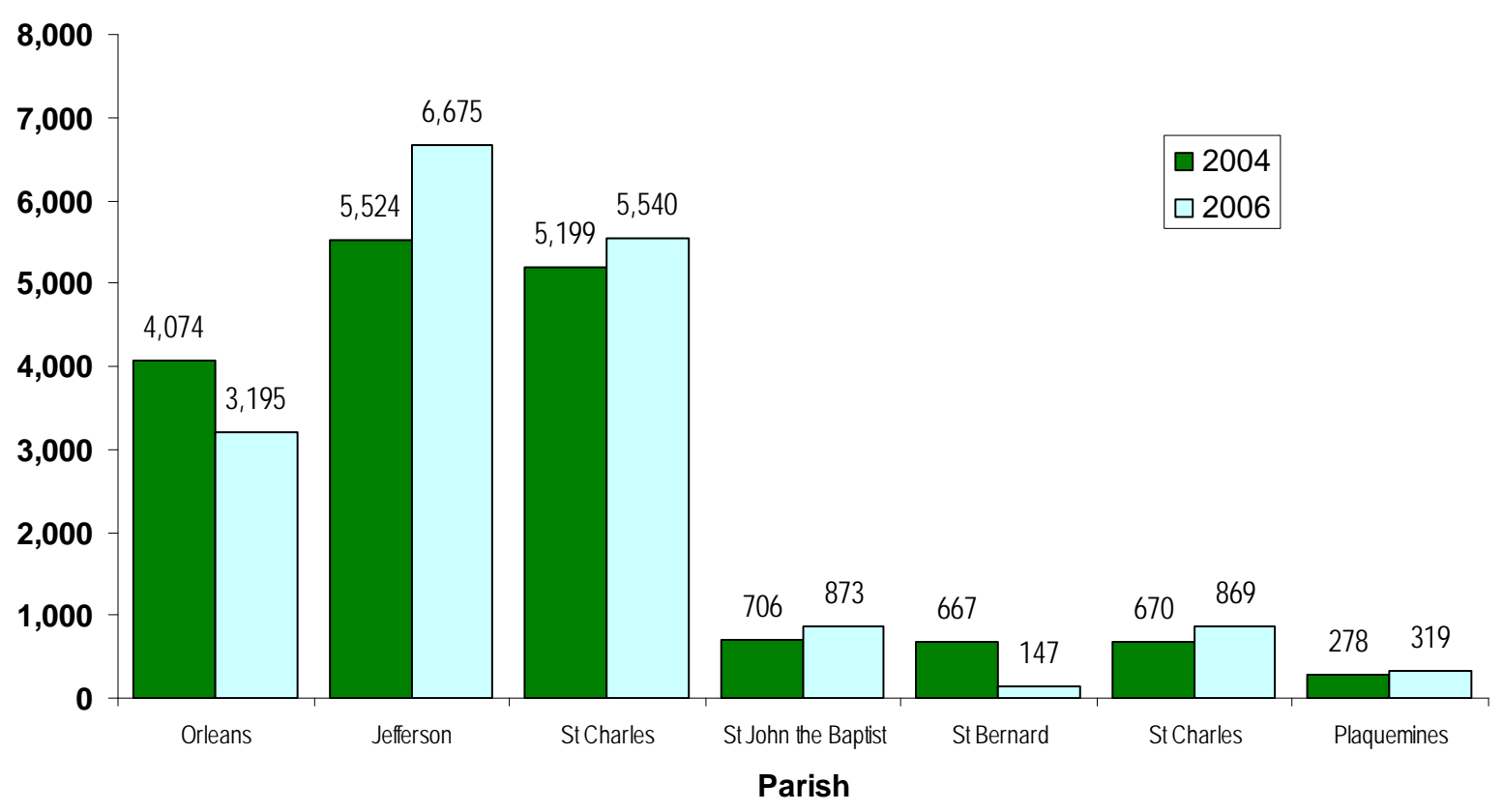


Figure 10. Percent of First-Lien Home Purchase Loans Going to Owner-Occupants, New Orleans MSA, 2004 and 2006
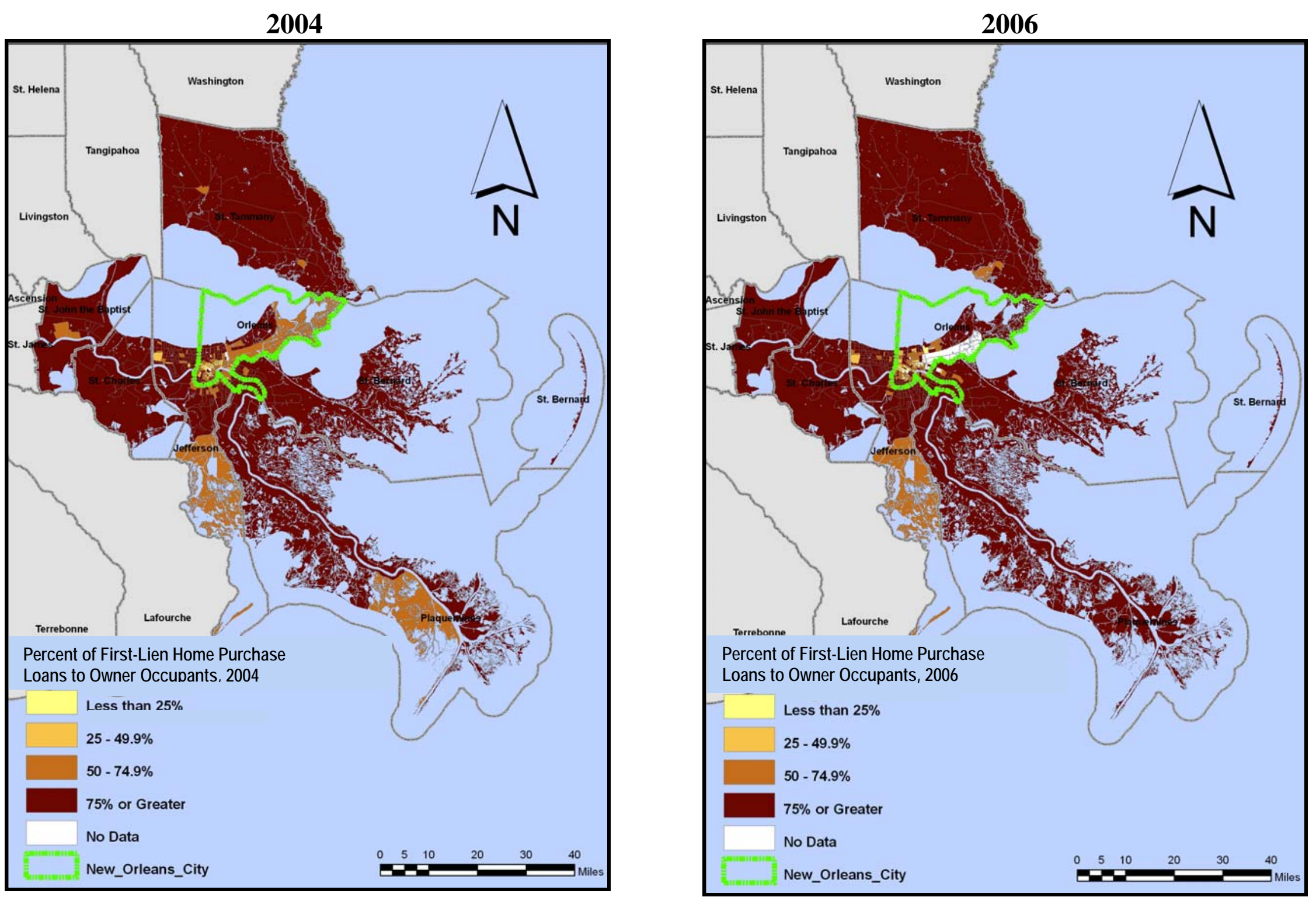
Figure 11. Percent of All First-Lien Home Purchase Loans Going to Owner-Occupants and Number of First-Lien Owner-Occupied Home Purchase Loans, by Planning District, 2004, 2006

Percent of All First-Lien Home Purchase Loans Going to Owner-Occupants

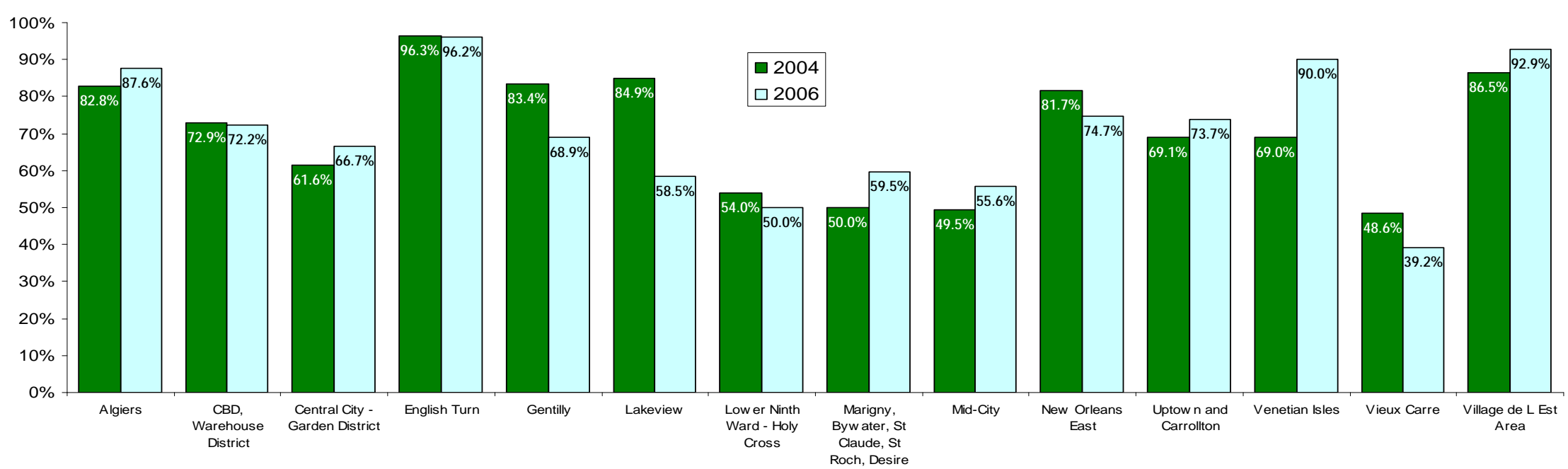

Number of First-Lien, Owner-Occupied Home Purchase Loans

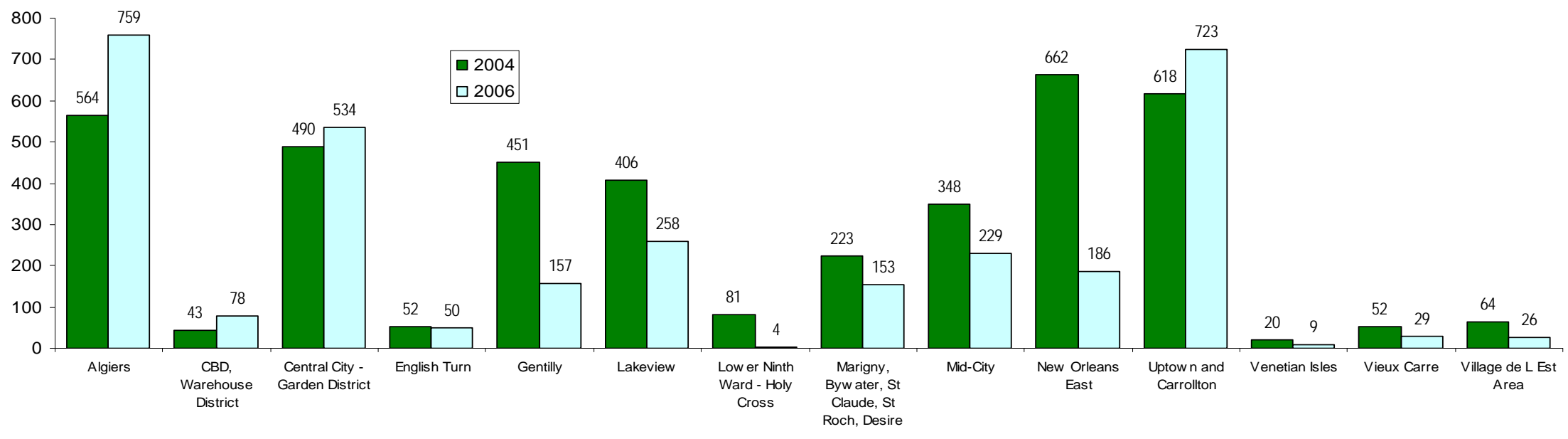


Figure 12. Percent of First-Lien Home Purchase Loans Going to Owner-Occupants, City of New Orleans, 2004 and 2006
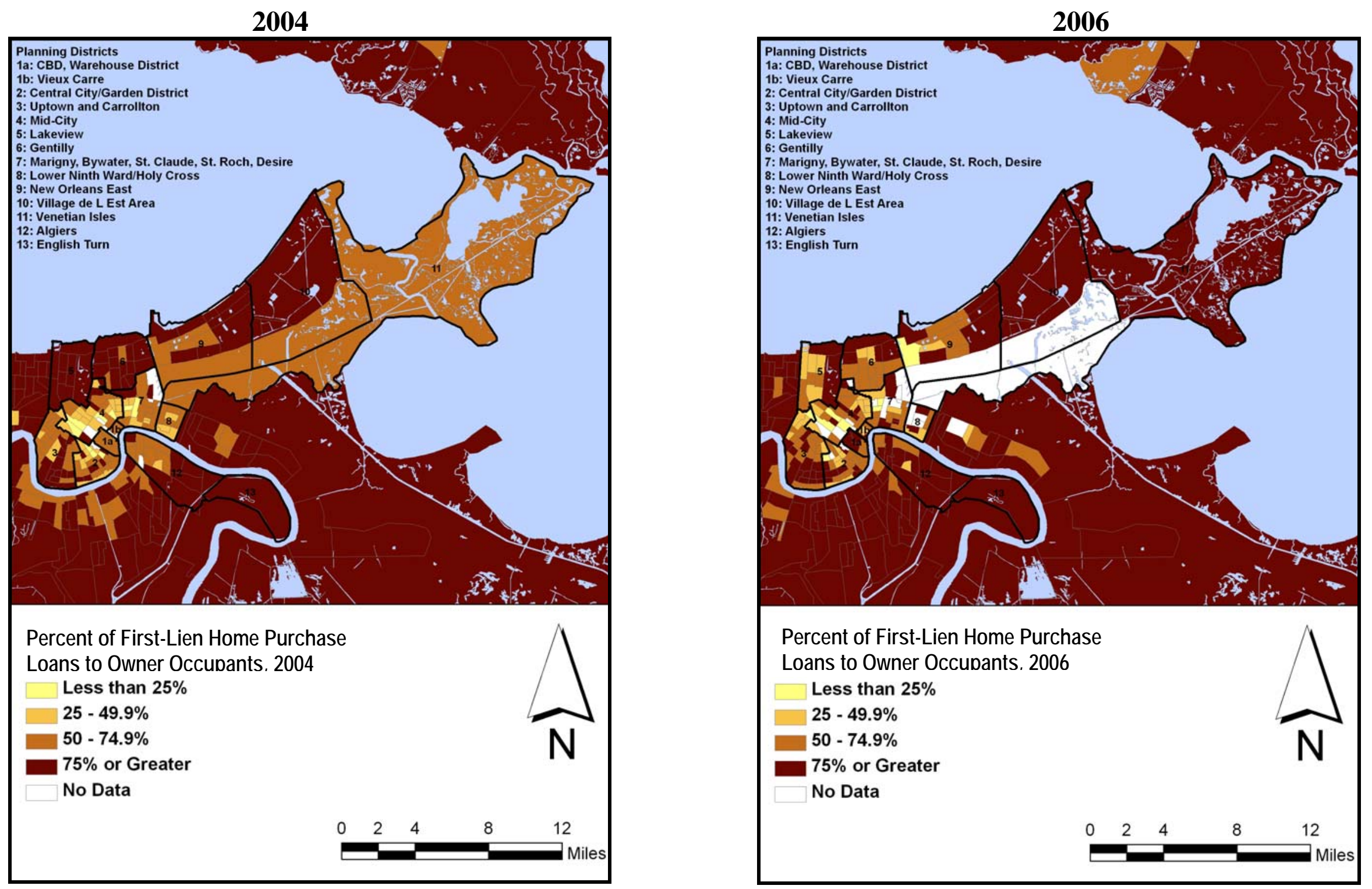
Figure 11 breaks out changes in owner-occupied percentages and raw numbers within the City of New Orleans by planning district. It shows that, at this smaller geographic level, owneroccupancy percentages did change substantially in some parts of the city. In particular, the Gentilly, Lakeview, New Orleans East, and Vieux Carre districts all saw the percentage of firstlien purchase loans going to owner-occupied properties decline by more than five percentage points. The largest percentage-point declines were in the Lakeview (84.9 percent to 58.5 percent) and Gentilly (84.9 percent to 68.9 percent) districts. At the same time, the percentage of purchase loans going to owner-occupied properties increases by more than five percentage points in Central City-Garden District, Marigny-Bywater, Mid-City, and Venetian Isles. The raw number of owner-occupied home buyers increased in Algiers, CBD-Warehouse, Central CityGarden District, and Uptown and Carrollton. Figure 12 illustrates the changes in the proportion of home purchase loans going to owner-occupiers from 2004 to 2006 at the census tract level for Orleans parish.

\section{Changes in the Race of Borrowers for First-Lien, Owner-Occupied Home Purchase Loans in the New Orleans Metropolitan Area, 2004 to 2006}

As was illustrated earlier, the New Orleans metropolitan area, like many others, was heavily segregated prior to Hurricane Katrina. We now turn to examining how the homebuying patterns of African-Americans changed after Katrina. Overall, the number of first-lien, owneroccupied home purchase loans to African-Americans in the New Orleans MSA fell from 3,424 in 2004 to 2,996 in 2006, and from 21.6 percent of all first-lien, owner-occupied home purchase loans in 2004 to 18.5 percent in 2006. 
At the parish level, Figure 13 shows that in 2004, just over 40 percent of owner-occupied homebuyers in the city of New Orleans were African-American. ${ }^{6}$ In St. John the Baptist parish the ratio was roughly the same. Almost 20 percent of homebuyers in Jefferson parish were African American in 2004, with the other parishes had ratios of all under 15 percent.

By 2006, there were some notable changes in the numbers and shares of AfricanAmerican buyers. In Orleans parish, the number of African-American buyers of owner-occupied homes fell from 1,533 to 892, and from 40.6 percent of all such buyers to 30.4 percent. The share in St. Bernard parish fell from 10.2 percent to 3.5 percent and from 9.5 percent to 6.2 percent in St. Tammany parish. Over the same period, however, the shares of African-American buyers increased in St. John the Baptist, St. Charles, and Plaquemines parishes, and held essentially flat in Jefferson parish.

Figure 14 provides a finer-grain picture of changes in the concentration of AfricanAmerican homebuyers from 2004 to 2006. It confirms the general increase of African-American homebuying in some places, including northern parts of St. John the Baptist parish. But it shows that some tracts that had 75 percent or more African-American homebuying in 2004 had a lower percentage in 2006. This includes tracts on the east side of the city, but also in parts of St. John the Baptist and Jefferson parishes.

Figure 15 breaks out changes in the percentages of homebuyers who are black by planning district within the city of New Orleans. It shows that some districts experienced substantial drops in the proportion of owner-occupied homebuyers who were African-American, including CBD-Warehouse District, Marigny-Bywater, and Mid-City. However, the stronger reason for the decline in the share of city homebuyers who were African-American was the

\footnotetext{
${ }^{6}$ Figures 13 and 15 also indicate the percentages of first-lien, owner-occupied home purchase loans where race was not reported. Where these percentages are large relative to the percentage of reported African-American buyers, special care should be taken in the interpretation of the numbers or shares of African-American buyers.
} 
Figure 13. Percent of First-Lien Owner-Occupied Home Purchase Loans Going to AfricanAmerican Homebuyers, by Parish, 2004 and 2006

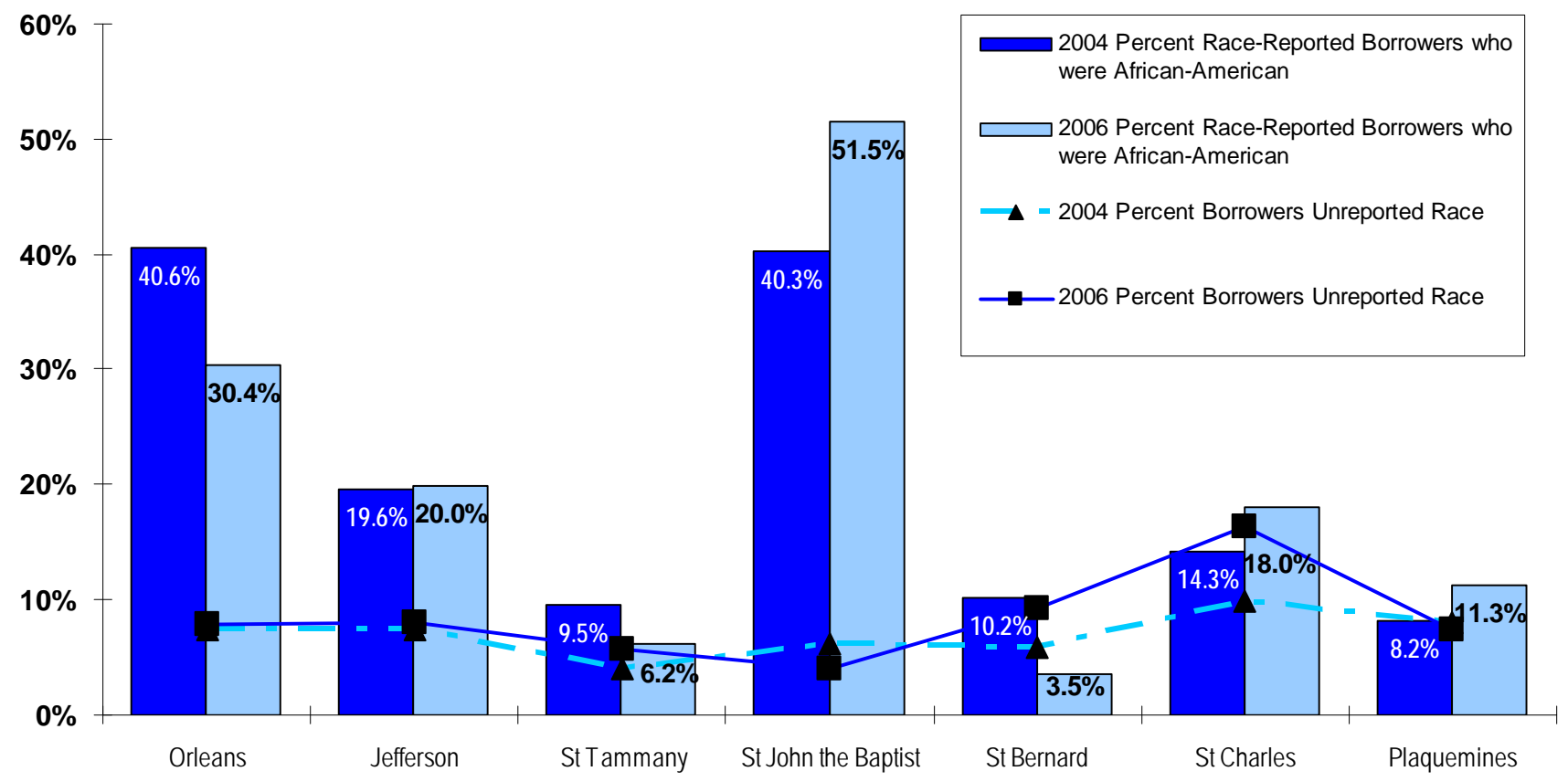


Figure 14. Percent of First-Lien, Owner-Occupied Home Purchase Loans to African-Americans, New Orleans MSA, 2004 and 2006
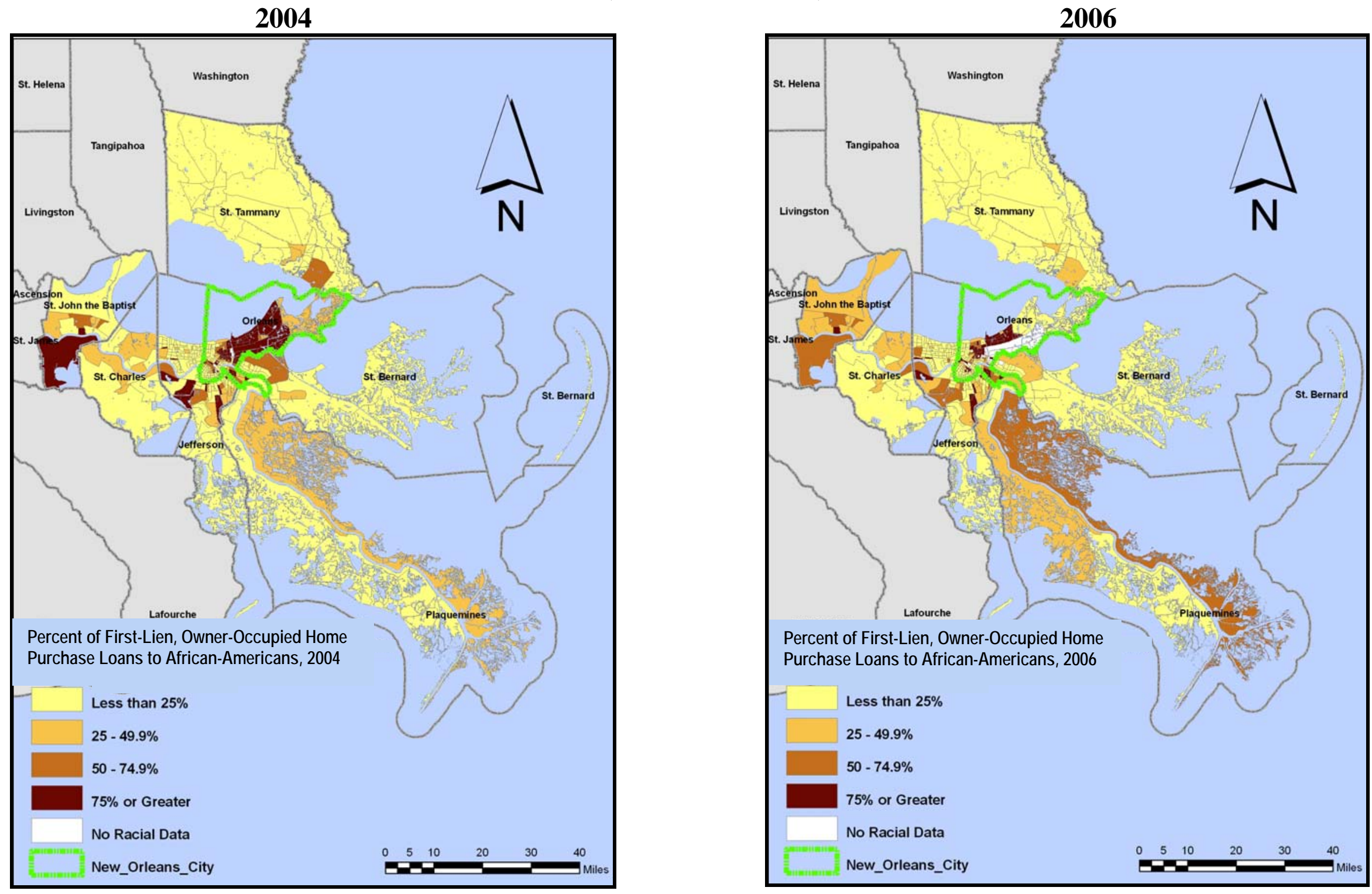
Figure 15. Percent of First-Lien Owner-Occupied Home Purchase Loans Going to African-American Homebuyers, by City of New Orleans Planning District, 2004 and 2006

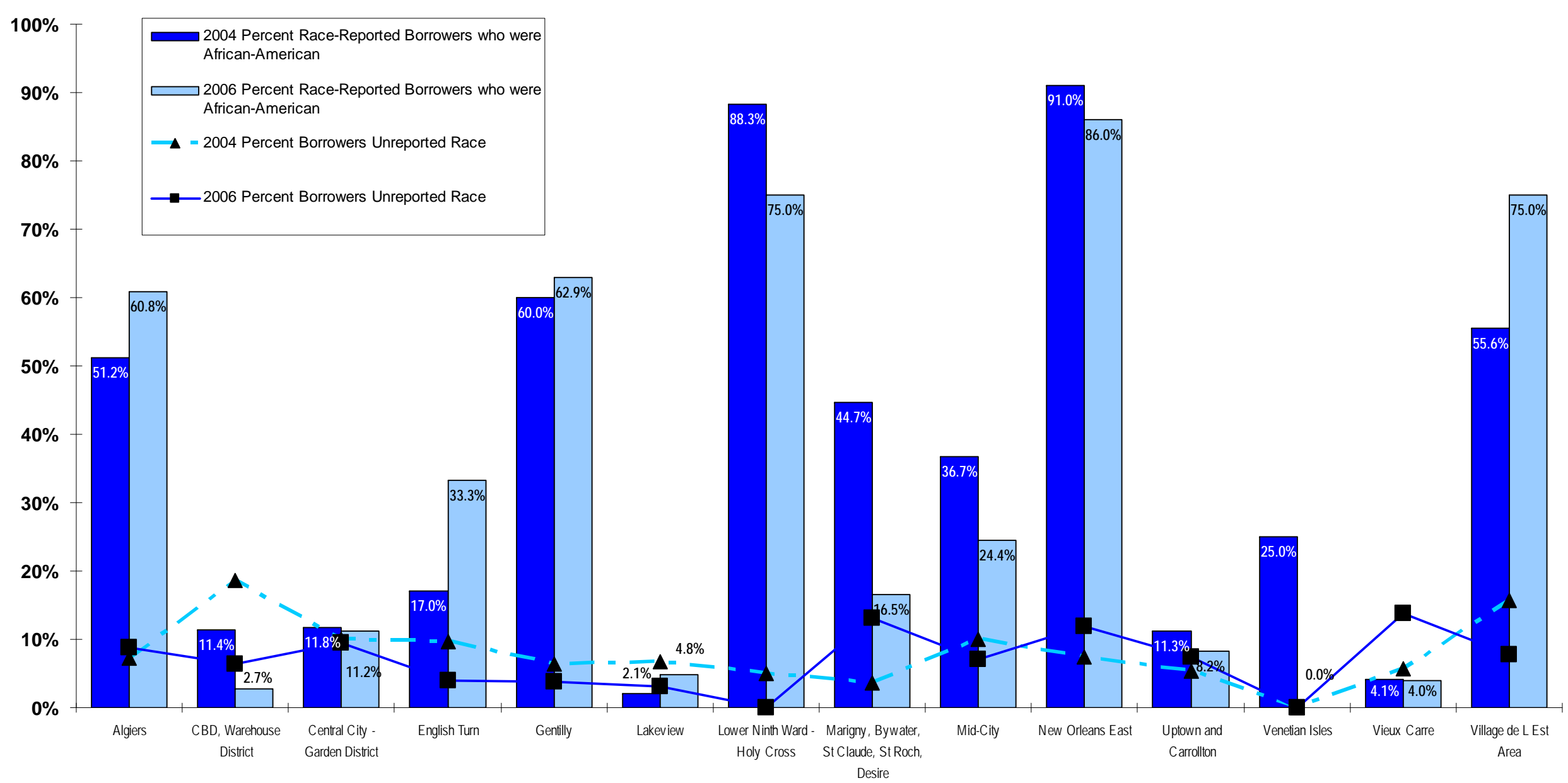


Figure 16. Percent of First-Lien, Owner-Occupied Home Purchase Loans to African-Americans, City of New Orleans, 2004 and 2006
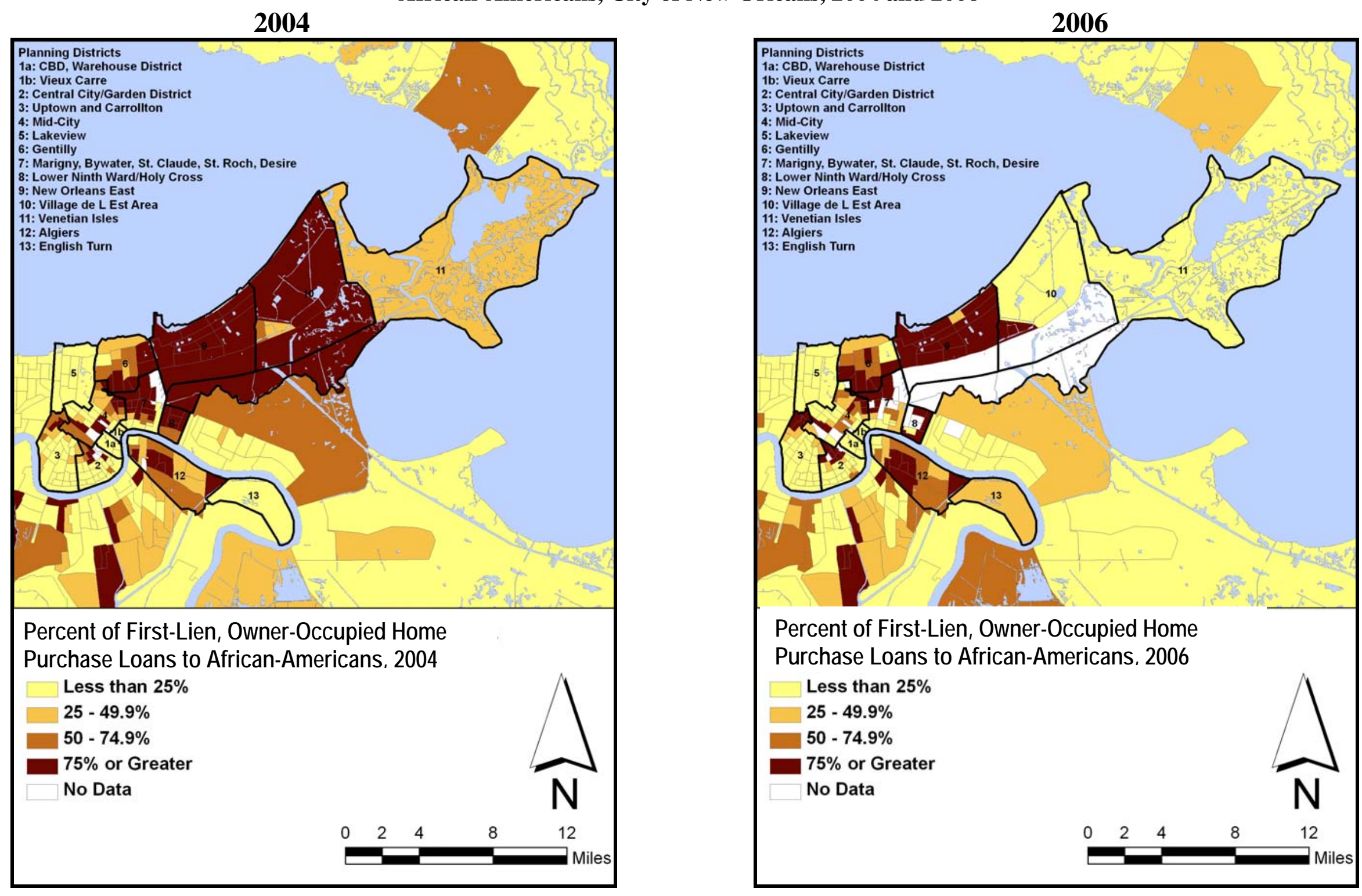
overall decline in the amount of purchase loans in the three districts with high percentages of African-American homebuying (in both 2004 and 2006): the New Orleans East, Gentilly, and Lower Ninth-Holy Cross districts. The other district with substantial raw numbers of AfricanAmerican homebuyers in 2004 - Algiers-actually saw an increase in buyers in 2006, and a higher percentage of African-American buyers. Figure 16 illustrates changes in the AfricanAmerican share of owner-occupied homebuyers from 2004 to 2006 at a census tract level for the city.

\section{Changes in the Income of Borrowers for First-Lien, Owner-Occupied Home Purchase Loans in the New Orleans Metropolitan Area, 2004 to 2006}

In addition to examining the race of homebuyers, the HMDA data also allow us to look at changes in the incomes of buyers of owner-occupied homes in the New Orleans area from before to after Katrina. Overall, the New Orleans MSA saw a sharp decline in the proportion of buyers who had low- or moderate-incomes, dropping from 28.8 percent to 19.9 percent, for a drop in share of more than 30 percent. $^{7}$

The three charts in Figure 17 indicate changes in the shares of owner-occupied home buyers who were low- and moderate-income (less than 80 percent of metropolitan median family income), middle-income (80 to less than 120 percent of metropolitan median family income) and upper-income (120 percent or more of metropolitan median family income), respectively. The top chart shows that, in every parish other than Plaquemines, the share of buyers who had low-

\footnotetext{
${ }^{7}$ It happens that the national proportion of homebuyers with low- and moderate-incomes declined from 2004 to 2006 as well, but only from 31.2 percent to 26.3 percent, a decline of less than 16 percent compared to the 30 percent in the New Orleans MSA. The national decrease was likely due to a substantial increase over this period in lending activity in higher-cost metropolitan areas (e.g., CA, FL) where homebuyers are relatively affluent compared to the metropolitan median income. From 2004 to 2006, the New Orleans metro's percentage of low- and moderate income buyers dropped from 92 percent of the national percentage to 76 percent of the national percentage.
} 
Figure 17. Percent of First-Lien, Owner-Occupied Home Purchase Loans to Borrowers of Different Income Levels, by Parish, 2004 and 2006
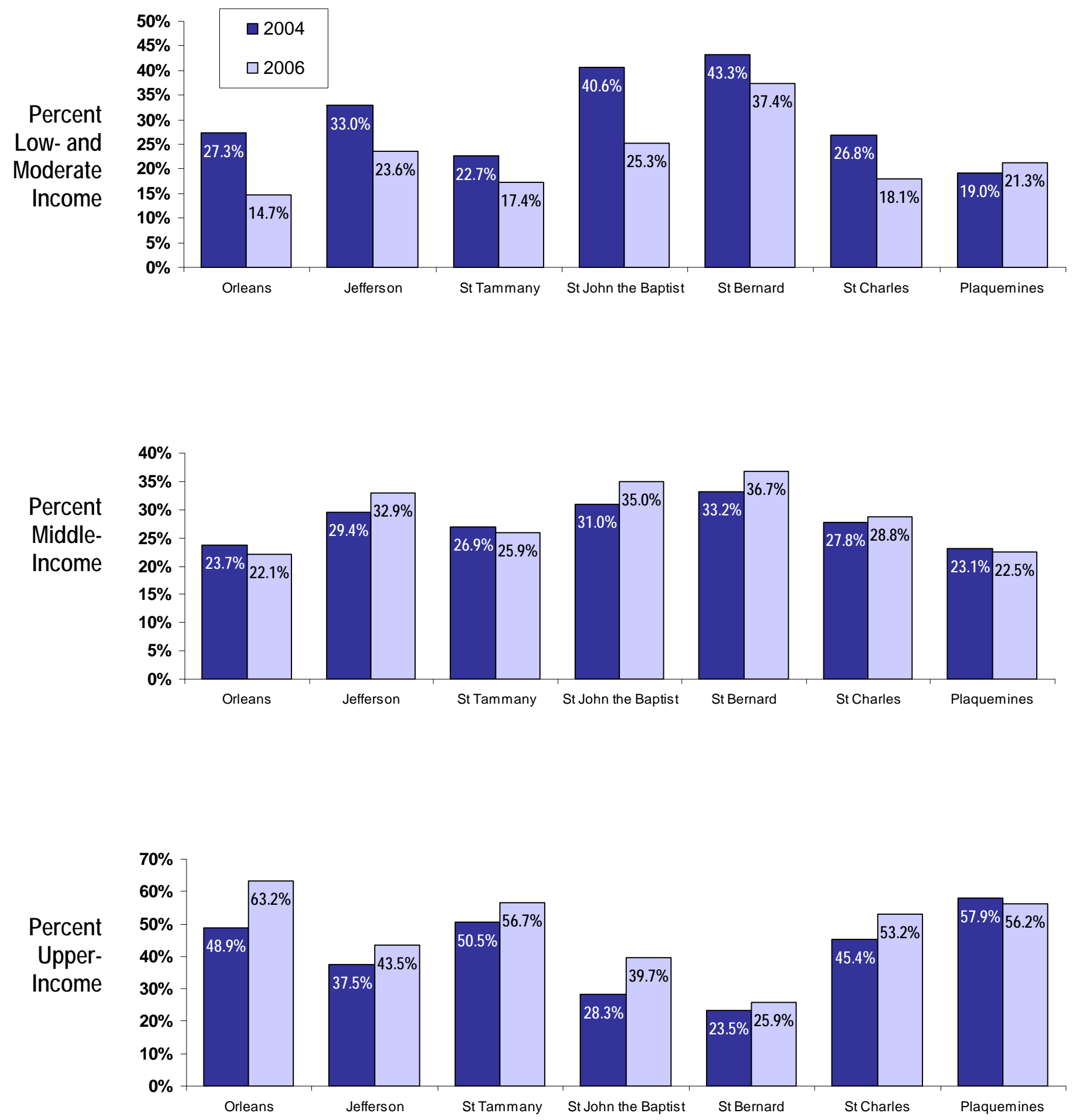
or moderate-incomes declined, sometimes quite sharply. ${ }^{8}$ In Orleans parish, the share of homebuyers with low- and moderate-incomes declined by more than 46 percent, from 27.3 percent to 14.7 percent. The declines in the other parishes with falling percentages were also substantial.

Examining the middle and bottom charts in Figure 17 shows that the decline in the lowand moderate-income shares in the MSA were due primarily to gains in the percentages of buyers falling into the upper-income bracket, especially in Orleans parish. That is, in most parishes, the percentage point gain in the percentage of upper-income buyers exceeded any gain in the percentage of middle-income buyers. For example, in Jefferson parish, the upper-income share increased by 6 percentage points, compared to a 3 percentage point increase in middleincome buyers. In St. John the Baptist, an 11.4 percentage point increase in upper-income share was almost triple the increase in middle-income share. And in St. Charles, a 7.8 percentage point increase in upper-income share far outpaced the meager 1 percentage point increase in middleincome share.

In fact, in Orleans parish, the share of buyers with middle incomes actually declined slightly (in addition to the low- and moderate-income share), so that the substantial increase in upper income buyers came at the expense of both low- and moderate-income and middle-income share. Figure 18 shows that, within the city of New Orleans, many districts saw a decline in the share of buyers with low- and moderate-incomes. Only Lakeview, Venetian Isles, and Village de L'est Area saw increases in their share of buyers with low- and moderate incomes. Figures 19 and 20 illustrate the changes in the percentage of buyers with upper-incomes at the census tract

\footnotetext{
${ }^{8}$ Of course, there is some issue with using HUD median family incomes as baselines for this analysis. These are estimates and are unlikely to be highly accurate in the New Orleans metropolitan area in 2006. However, because the median family income is higher in 2006 than 2004 (52,300 vs. 49,900), the absolute thresholds (in nonadjusted dollars) increased from 2004 to 2006. Thus the large, overall decline in borrowers under 80 percent of MSA median income was not due to some substantial lowering of the 80 percent threshold.
} 
Figure 18. Percent of First-Lien, Owner-Occupied Home Purchase Loans to Borrowers of Different Income Levels, by City of New Orleans Planning District, 2004 and 2006
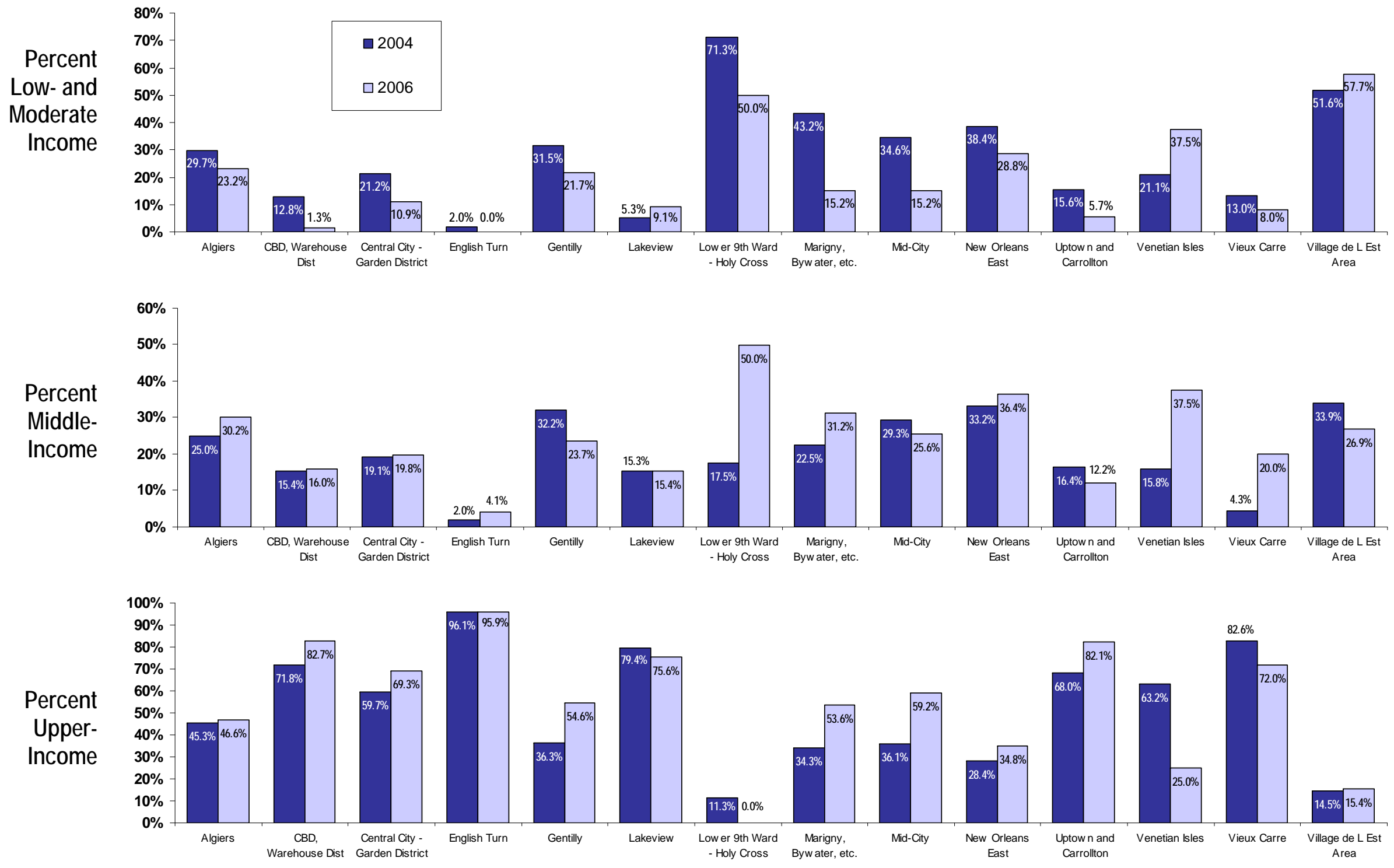
Figure 19. Percent of First-Lien, Owner-Occupied Home Purchase Loans to Upper-Income Buyers. New Orleans MSA, 2004 and 2006

\section{4}
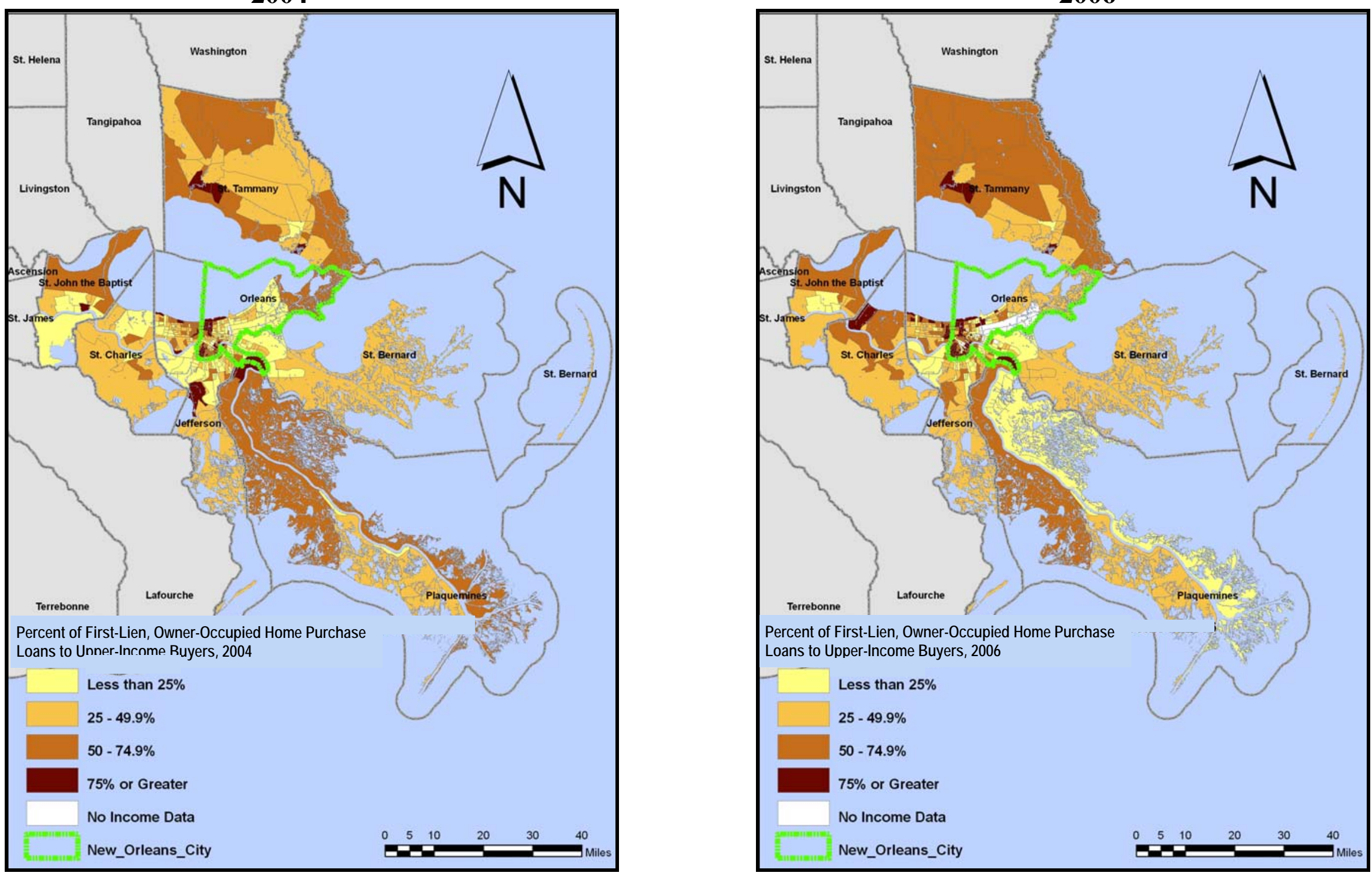
Figure 20. Percent of First-Lien, Owner-Occupied Home Purchase Loans to Upper-Income Buyers. City of New Orleans, 2004 and 2006
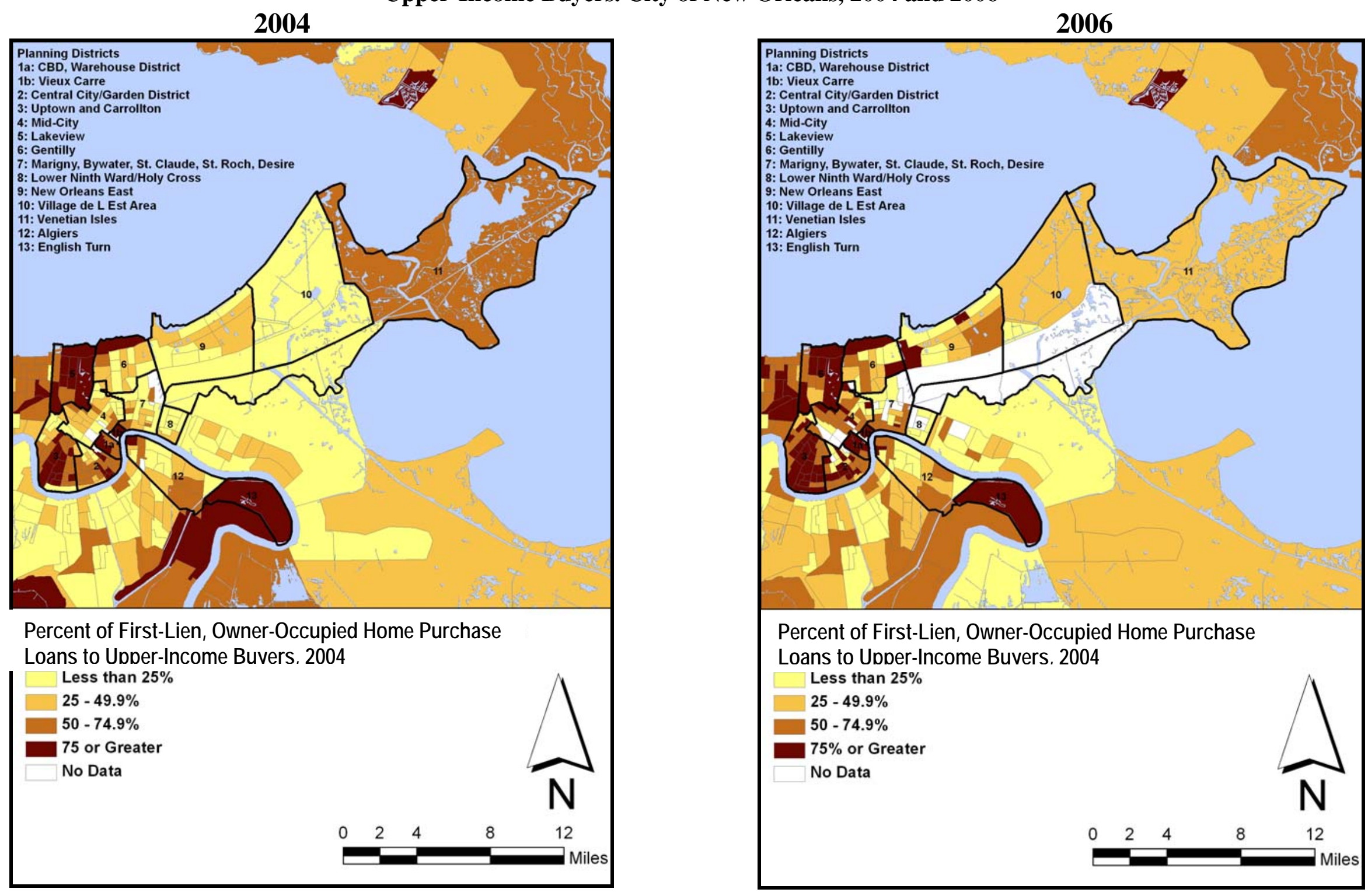
level for the MSA and city, respectively. Figure 19 suggests that the city, especially the west side of the city, saw a significant shift toward upper-income homebuying from 2004 to 2006.

\section{Changes in the Distribution of High-Cost Home Lending in the New Orleans Region, 2004 to 2006}

In addition to examining changes in the spatial distribution of homebuyers by race and income, we can also examine the shares of home purchase loans with subprime pricing in different parts of the metropolitan area and how these shares changed from 2004 to 2006. Subprime loans have been shown to disproportionately exhibit disadvantageous terms and pricing and have led to severe and spatially concentrated foreclosure problems, particularly in recent years (Immergluck, 2008). Subprime shares might also be expected to be higher in areas subject to greater flooding or water risks. This is in part because while federally regulated lenders are required to ensure that borrowers in flood plains obtain flood insurance, stateregulated lenders may not be, or may be subject to less scrutiny in this area. Moreover, loans sold to Fannie Mae or Freddie Mac, which tend not to be subprime loans, generally require flood insurance if the property is located in a floodplain. Because some of the largest subprime lenders are state-regulated - and tend not to sell loans to Fannie Mae or Freddie Mac - subprime lenders may have been less likely to require flood insurance.

Measuring changes in subprime loan share is complicated by the fact that national share of total home purchase loans that were subprime nationally and in the New Orleans MSA increased significantly from 2004 to 2006. This is in part because the pricing threshold over which a loan is considered classified as a high-rate loan - and thus classified as subprime here ${ }^{9}$

\footnotetext{
${ }^{9}$ Technically the term subprime is not used in the HMDA data. Loans above a certain pricing threshold have their Annual Percentage Rate (APR) reported, so sometimes are called "rate-reported" loans. Loans above this threshold are generally subprime or Alt-A (near subprime) in nature.
} 
- changes from year to year based on long-term Treasury bond rates, while the pricing of loans themselves may vary from such rates. In the HMDA data from 2004 on, the Annual Percentage Rate (APR) of a loan is reported if it exceeds the interest rate on a treasury bond of comparable term (e.g., 10, 20 or 30 years) plus three percentage points (for first-lien loans, which are the focus here). However, the interest rates of such securities rise and fall depending on macroeconomic interest rate conditions. Thus, in some years the comparable treasury rate may be relatively higher (compared to mortgage rates) than in other years. In fact, differences between typical mortgage rates and long term treasury rates were larger in 2004 than in 2006. This means that, overall, fewer higher priced loans would exceed the comparable-term Treasury rate plus three percentage points in 2004 than in 2006. Therefore, nationally, while only 11.5 percent of all first-lien home purchase loans exceeded the Treasury plus 3 percentage point threshold in 2004, 25.3 percent of first-lien purchase loans exceeded this threshold in 2006. However, it is also true that there was almost certainly a real increase in higher-risk and highercost lending over the 2004 to 2006 period, especially in high-cost markets such as California and Florida as well as many other regions.

Figure 21 indicates the subprime shares of different parishes within the MSA in 2004 and 2006. The top chart indicates the raw percentage of loans in each parish that were subprime and the change in this figure over the two year period. As one can see, subprime share increased in all parts of the MSA, even those not substantially impacted by Hurricane Katrina. However, this is most likely not due to a substantial region-specific increase in subprime lending but do to the previously described "threshold” effect, in which the number of loans classified as subprime in the HMDA data from 2004 to 2006. Similarly, in the New Orleans MSA, while only 12.8 
Figure 21. Subprime Shares and MSA-relative Ratios for First-lien Home Purchase Loans, Seven MSA Parishes, 2004 and 2006

\section{Subprime Percentage for First-Lien Home Purchase Loans by Parish}

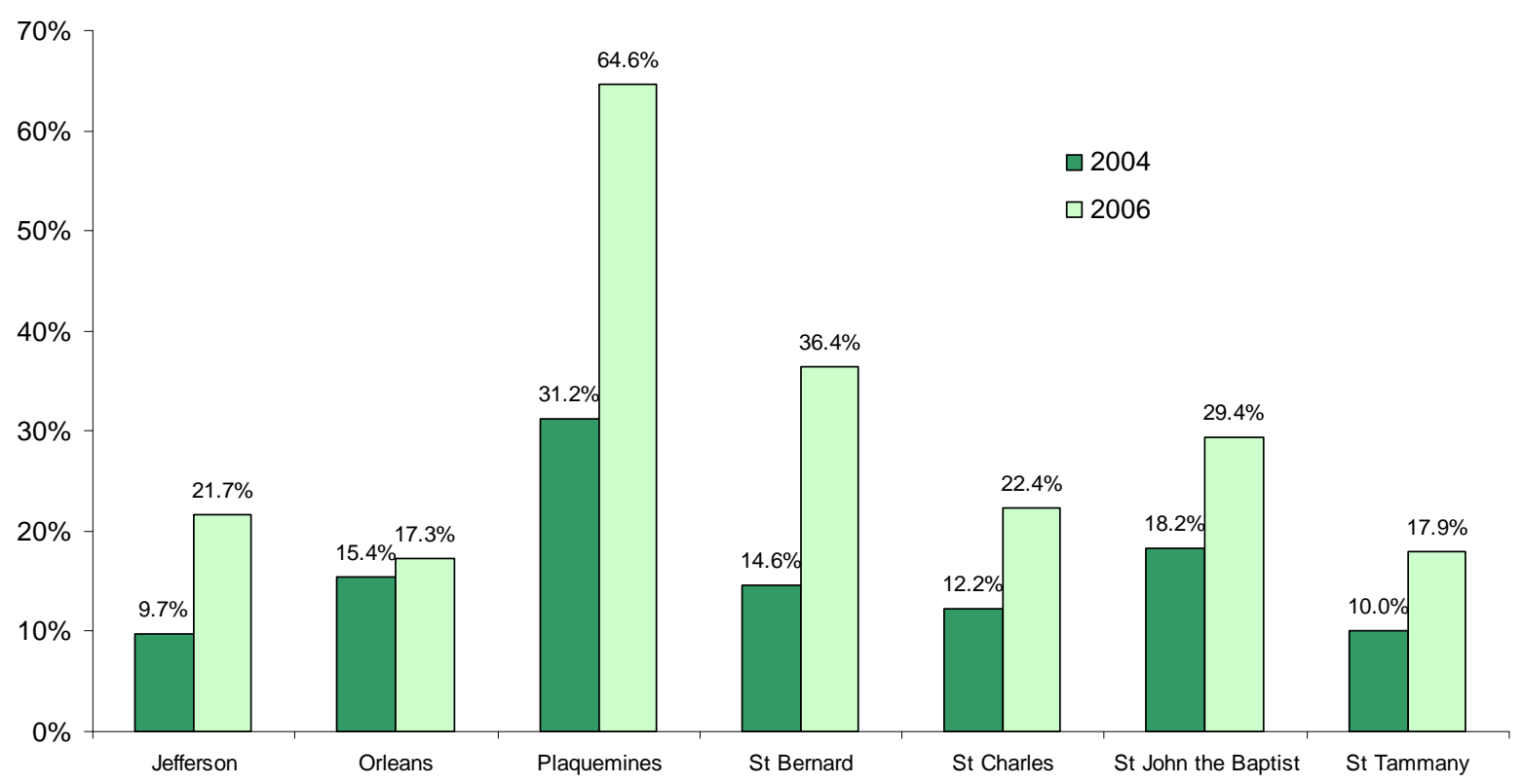

Parish Subprime Percentage for First-Lien Home Purchase Loans MSA Subprime Percentage for First-Lien Home Purchase Loans

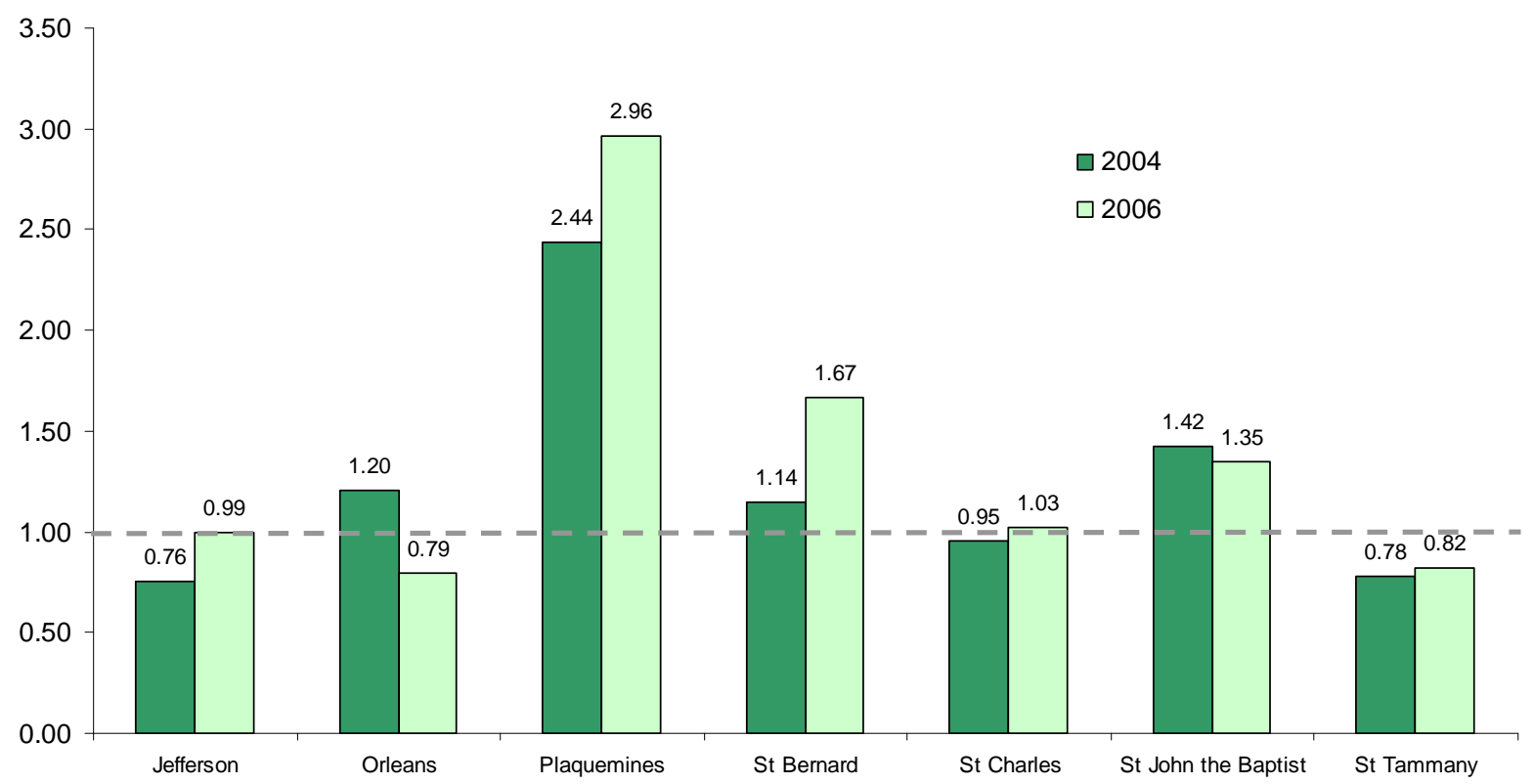


percent of first-lien purchase loans exceeded the rate-reporting threshold in HMDA (and therefore labeled "suprime" here) in 2004, 21.8 percent did in 2006. It is important to note that in 2004, the MSA's subprime share was 11 percent higher than the nation's, while in 2006, it was 14 percent lower. However, this was most likely due to substantial increases in subprime lending in high-cost markets such as California and Florida over this period.

To account for the shift in the pricing threshold in the definition of subprime loans, we developed "MSA-relative" subprime ratios, shown in the bottom chart in Figure 21, which are equal to the local area (in this case, the parish) subprime share divided by the subprime share for the entire MSA in the same year. This ratio equals one when an area's subprime share is the same as the MSA's as a whole. A ratio of 1.5 means that a local area has a 50 percent greater subprime share than the MSA, and a ratio of 0.67 means that the MSA has a 50 percent greater subprime share than the local area.

The lower chart in Figure 21 shows that the MSA-relative subprime ratio decreased substantially in Orleans parish, so that the parish's subprime share was 1.2 times the MSA share in 2004 but only 0.79 times the MSA share in 2006. No other parish saw a substantial decline in MSA-relative share, although the ratios were relatively stable in St. John the Baptist (1.42 to 1.35), St. Charles (0.95 to 1.03 ), and St. Tammany (0.78 to 0.82). Meanwhile, Jefferson, Plaquemines, and St. Bernard parishes saw substantial increases in their MSA-relative subprime ratios, with gains from 0.76 to 0.99 in Jefferson, 2.44 to 2.96 in Plaquemines, and 1.14 to 1.67 in St. Bernard.

Figure 22 provides similar analysis to that in Figure 21, but for planning districts within the city of New Orleans. Again, changes in overall subprime share and the subprime pricing threshold mean that the lower chart in Figure 22 is more meaningful for comparing subprime 
Figure 22. Subprime Shares and MSA-relative Ratios for First-lien Home Purchase Loans, City of New Orleans Planning Districts, 2004 and 2006

\section{Subprime Percentage for First-Lien Home Purchase Loans by City Planning District}

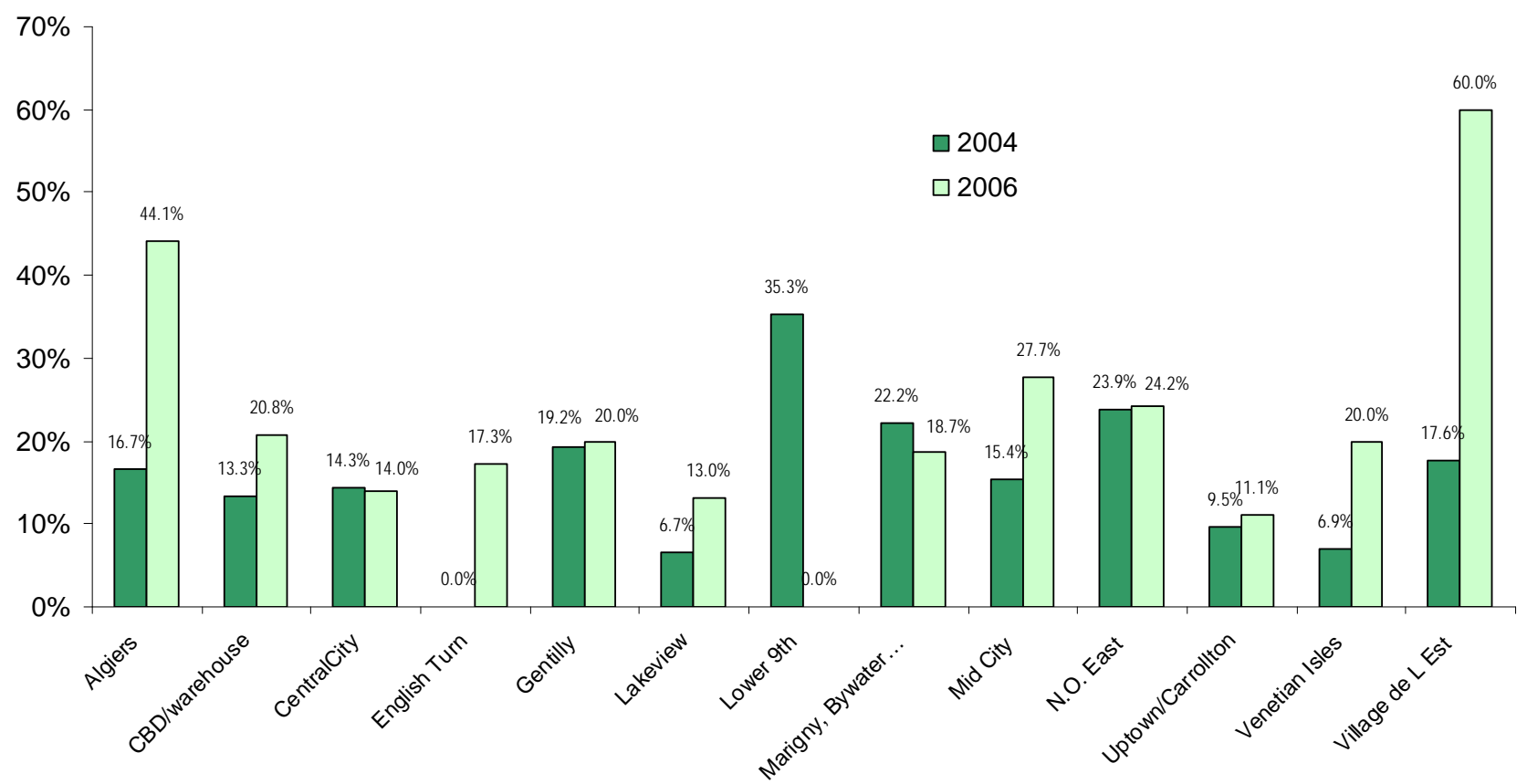

Planning District Subprime Percentage for First-Lien Home Purchase Loans MSA Subprime Percentage for First-Lien Home Purchase Loans

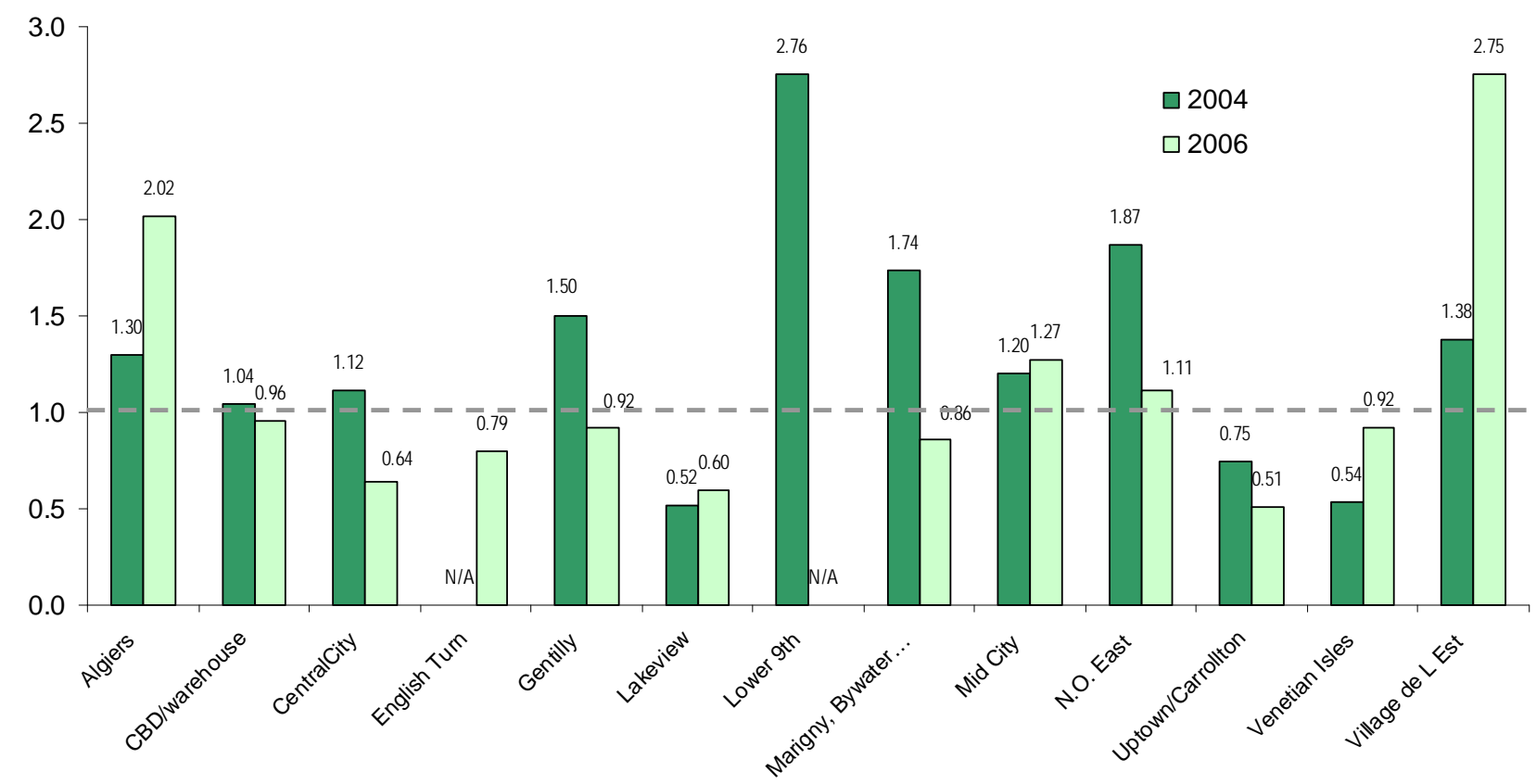


Figure 23. MSA-Relative Subprime Share by Tract, Home Purchase Loans City of New Orleans, 2004 and 2006
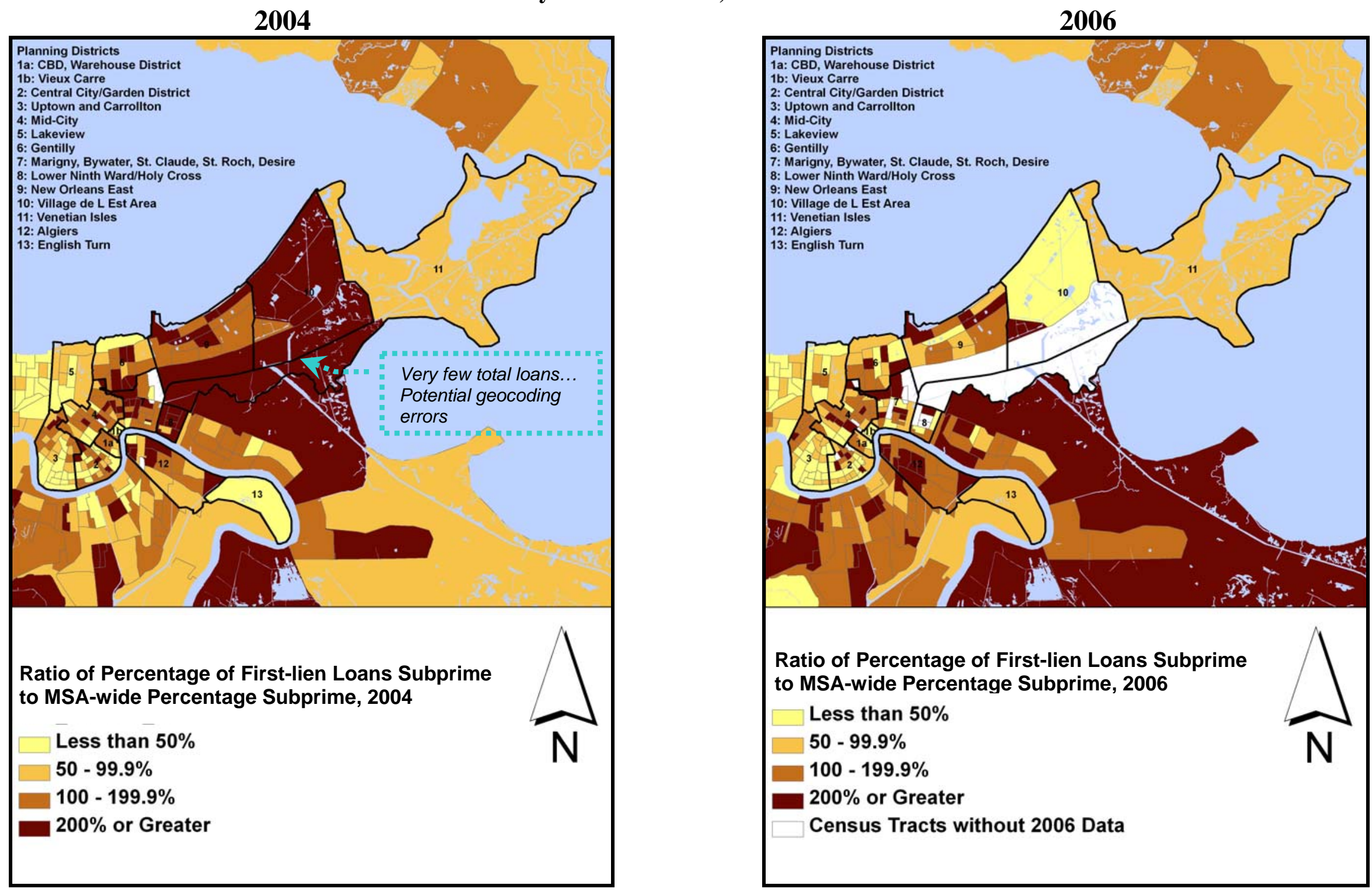
penetration across planning districts. It shows that the MSA-relative subprime ratio increased somewhat in Algiers, Venetian Isles and Village de L'est, but fell in almost all other planning districts, or remained roughly stable (CBD Warehouse, Lakeview, and Mid-City). In the Lower $9^{\text {th }}$ ward-Holy Cross district, lending essentially declined to a negligible level. In 2004, the district had the highest MSA-relative subprime ratio of any planning district in the city. Figure 23 plots the MSA-relative ratios across the city. It corroborates the planning-district patterns indicated in Figure 22, but also shows that subprime levels south of the river near Algiers also increased at higher than the metropolitan rate. This may be reflecting a potential shift of residential buyers into these communities, and the subprime loans "following” such homeowners.

\section{Measures of Racial and Economic Segregation in Homebuying before and after Katrina.}

In order to understand whether the patterns of segregation in owner-occupied homebuying changed after Katrina, we computed measures of spatial segregation of homebuying by both race and income. We began by calculating the dissimilarity index of black versus nonblack homebuyers across the 388 census tracts in the seven-parish MSA, and then developed a measure of the evenness of the distribution of low-income homebuyers by calculating a dissimilarity index for low-income versus other homebuyers. To provide some test of robustness of these indicators we also looked at the issue of exposure of black buyers to nonblack buyers at the census tract level by calculating an isolation index for black buyers. All of these indicators were calculated for 2000 total population (not homebuyers only) data from the 2000 census for comparison purposes as well as for 2004 and 2006 homebuying data separately.

The dissimilarity index used is the standard one of the form: 


$$
D=\sum_{i=1}^{N} \frac{t_{i}\left|p_{i}-P\right|}{2 T P(1-P)}
$$

Where $t_{i}$ is the total number of financed homebuyers in tract $i, p_{i}$ is the proportion of black buyers in tract $i, \mathrm{P}$ is the proportion of all MSA buyers who are black, $\mathrm{T}$ is the total number of MSA buyers, and $\mathrm{N}$ is the number of tracts in the MSA. $\mathrm{D}$ ranges from 0 to 1 , with 1 indicating perfect unevenness in the spatial distribution of black buyers.

The measure of exposure used is the isolation index, given by:

$$
I=\sum_{i=1}^{N}\left[\left(\frac{m_{i}}{M}\right) *\left(\frac{m_{i}}{t_{i}}\right)\right]
$$

Where, in this case, $m_{i}$ is the number of financed black owner-occupied homebuyers in tract $i, M$ is the total number of black homebuyers in the MSA, and $t_{i}$, again, is the total number of financed homebuyers in tract $i$. I also ranges from 0 to 1 , with 1 indicating perfect isolation. In its use here, an I of 1 would reflect a zero probability of black residents buying homes in a tract where at least one nonblack buyer exists.

We measure the dissimilarity index for homebuying by income and race, but, for the sake of conciseness, we only measure the isolation index by race. We calculated these measures for 2004 and 2006 to identify whether there appears to be a difference in the "spatial sorting” of homebuyers by race or income immediately after Katrina. We also provided the 2000 racial indices for residents as a whole for comparison purposes. 
Table 1 indicates the dissimilarity and isolation indices for three types of households/persons. First, the black-white dissimilarity and isolation indices were calculated using census tracts as the geographic unit for the 388 tracts in the New Orleans MSA based on 2000 census data for all residents. We also indicate the proportion of the index that is accounted for by the 181 tracts in the City of New Orleans.

Table 1 indicates that in 2004, African-Americans were, as measured by the dissimilarity index, geographically distributed across the MSA to essentially the same extent ( 0.69 versus 0.67) as African-American residents were in 2000. However, the isolation index is somewhat lower for 2004 African-American homebuyers as compared to all residents in 2000, suggesting more exposure of black homebuyers to nonblack buyers vis-à-vis the 2000 pattern of overall isolation levels of blacks in 2000 in the MSA.

Table 1 also shows that measured both by dissimilarity and isolation indices, the segregation of black homebuyers declined somewhat from 2004 to 2006, with the dissimilarity ratio declining to 0.62 , from 0.69 , and the isolation index declining from 0.55 to 0.49 . It is important to point out here, however, that the overall number of black buyers and the share of all buyers who were black declined significantly from 2004 to 2006, and this likely accounts for a substantial portion of these changes.

\section{Conclusions}

Through the analysis of Home Mortgage Disclosure Act data we have identified demographic shifts among hombuyers in New Orleans from 2004 to 2006. The data reveal that there have been significant shifts in homebuying activity within the metropolitan area as well as declines in African-American and lower-income hombuyers relative to other buyers. Declines in 
Table 1. Changes in Racial and Economic Segregation in Homebuying Patterns, 2004 to 2006

\begin{tabular}{llllll}
\multicolumn{2}{c}{2000} & Census & \multicolumn{2}{c}{ 2004 Homebuyers } & \multicolumn{2}{c}{2006 Homebuyers } \\
MSA & City Share & MSA & City Share & MSA & City Share \\
\hline
\end{tabular}

Racial Segregation Indices

\begin{tabular}{|c|c|c|c|c|c|c|}
\hline Black-nonblack dissimilarity & 0.67 & $\begin{array}{r}0.31 / 0.67 \\
(46 \%)\end{array}$ & 0.69 & $\begin{array}{r}0.24 / 0.69 \\
(35 \%)\end{array}$ & 0.62 & $\begin{array}{r}0.16 / 0.62 \\
(26 \%)\end{array}$ \\
\hline Black-nonblack isolation & 0.71 & $\begin{array}{r}0.55 / 0.71 \\
(77 \%)\end{array}$ & 0.55 & $\begin{array}{r}0.33 / 0.55 \\
(60 \%)\end{array}$ & 0.49 & $\begin{array}{r}0.19 / 0.49 \\
(39 \%)\end{array}$ \\
\hline
\end{tabular}

Income Segregation Index

$\begin{array}{lrrrrr}\text { Low-income-non-low-income } & \text { N/A } & \text { N/A } & 0.45 & 0.13 / 0.45 & 0.09 / 0.39 \\ \text { dissimilarity } & & & & (29 \%) & (23 \%)\end{array}$

Source: Authors calculations from 2000 census data and 2004, 2006 H.M.D.A data; all calculations use census tracts as geographic units 
African-American and lower-income homebuying in Orleans Parish is accounted for in large part by big declines in homebuying in heavily storm-impacted neighborhoods that had been the locus of a large amount of African-American and lower-income homebuying before Katrina. There were also shifts within more active planning districts toward higher-income and nonblack buyers.

The decline in African-American and lower-income homebuyers after Katrina helped drive measures of racial and economic segregation of such buyers somewhat lower from 2004 to 2006. At first blush, such declines may be encouraging. However, many may be concerned that the overall share of modest-income and African-American buyers in the metropolitan area and, especially Orleans Parish, is merely a reflection of a lesser tendency of African-American and modest-income homebuyers to return to the city or to purchase homes in the region or city compared to middle- or upper-income households. As the number of African-American and lower-income buyers declines, indices measure evenness and exposure tend to decline.

This study is only able to examine homebuying in the year immediately following Hurricane Katrina (calendar year 2006). Moreover, the study says little about overall demographics of the city because it does not include information on renters or sellers of homes. However, the substantial changes in the racial and economic patterns of buyers following the storm suggests that the characteristics of those who purchased homes in different parts of the city and MSA did change substantially. It will be important to examine similar data for 2007 and beyond as they become available to see if such patterns continue. 


\section{References}

Comerio, M. 1997. Housing Issues After Disasters. Journal of Contingencies and Crisis Management 5: 166-178.

Fothergill, A., E. Maestas, and J. DeRouen Darlington. 1999. Race, Ethnicity, and Disasters in the United States: A Review of the Literature. Disasters 23:156-173.

Gabe, T., Falk, G., McCarty, M. and Mason, V. 2005. Hurricane Katrina: Social-demographic characteristics of impacted areas. Washington, D.C.: Congressional Research Service and the Library of Congress. November.

Hartman, C. and Squires, G. 2006. There is No Such Thing as a Natural Disaster: Race, Class, and Hurricane Katrina. New York: Routledge, 2006.

Immergluck, D. 2008. From the Subprime to the Exotic: Expanded Mortgage Market Risk and Implications for Metropolitan Communities and Neighborhoods. Journal of the American Planning Association 74 (1): 59-76.

Lindell, M. and C. Prater. 2003. Assessing Community Impacts of Natural Disasters. Natural Hazards Review 4: 176-185. 
Lindell, M. and C. Prater. 2003. Assessing Community Impacts of Natural Disasters. Natural Hazards Review 4: 176-185.

Logan, J. 2006. The Impact of Hurricane Katrina: Race and Class in Storm-Damaged Neighborhoods. Unpublished manuscript. February.

Murdock, J., H. Singh, and M. Thayer. 1993. The Impact of Natural Hazards on Housing Values: The Loma Prieta Earthquake. Journal of the American Real Estate and Urban Economics Association 21: 167-184.

Peacock, W.G. and C. Girard. 1997. Ethnic and Racial Inequalities in Hurricane Damage and Insurance Settlements. In W.G. Peacock, B.H. Morrow and H. Gladwin (eds.) Hurricane Andrew: Ethnicity, Gender, and the Sociology of Disasters. Routledge, New York.

Peacock, W.G., Y. Zhang, and N. Dash. 2005. Long Term Single Family Housing Recovery. The Case of Hurricane Andrew and Miami-Dade County. Paper presented at the Hazard and Disaster Researchers Meeting, Boulder, Colorado, July.

Quarantelli. E. L. 1995. Patterns of Sheltering and Housing in U.S. Disasters. Disaster Prevention and Management 4 (no. 3): 43-57. 
Quarantelli. E. L. 1999. The Disaster Recovery Process: What We Know and Do Not Know From Research. Preliminary Paper \#286. University of Delaware Disaster Research Center. http://dspace.udel.edu:8080/dspace/bitstream/19716/309/1/PP+286.pdf.

Scheessele. R. 1998. HMDA Coverage of the Mortgage Market. U.S. Department of Housing and Urban Development. Working paper HF-007. Retrieved April 22, 2008 from http://www.huduser.org/Publications/pdf/wkgpapr_7.pdf.

U.S. Office of the Federal Coordinator for Gulf Coast Rebuilding at the Department of Homeland Security. 2006. Current Housing Unit Damage Estimates Hurricanes Katrina, Rita, and Wilma. April 7. Retrieved on January 2, 2008 from http://www.huduser.org/publications/destech/GulfCoast_HsngDmgEst.html. 